\author{
UNITED STATES \\ DEPARTMENT OF THE INTERIOR \\ GEOLOGICAL SURVEY
}

\title{
'PRELIMINARY APPRAISAL OF THE HYDROLOGY OF THE BLOCKER AREA, PITTSBURG COUNTY, OKLAHOMA
}

By Melvin V. Marcher, DeRoy L. Bergman, Jerry D. Stoner, and Stephen P. Blumer

U.S. GEOLOGICAL SURVEY

WATER-RESOURCES INVESTIGATIONS

OPEN-FILE REPORT 81-1187

Prepared in cooperation with the US. BUREAU OF LAND MANAGEMENT under the

Energy Minerals Rehabilitation Inventory and Analysis Program 


\title{
UNITED STATES DEPARTMENT OF THE INTERIOR JAMES G. WATT, Secretary
}

\author{
GEOLOGICAL SURVEY \\ Dallas L. Peck, Director
}

For additional information write to:

James H. Irwin, District Chief

U.S. Geological Survey

Water Resources Division

Rm. 621, Old Post Office Bldg.

215 Dean A. Mc Gee Avenue

Oklahoma City, Ok 73102

Telephone : 405-231- 4256
Copies of this report can be purchased from:

Open-File Services Section

Western Distribution Branch

U.S. Geological Survey

Box 25425, Federal Center

Lakewood, Colorado 80225

(Telephone: (303) 234-5888) 


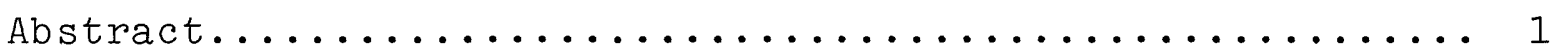

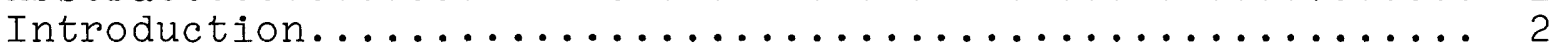

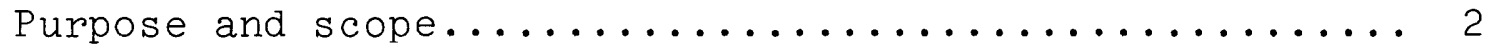

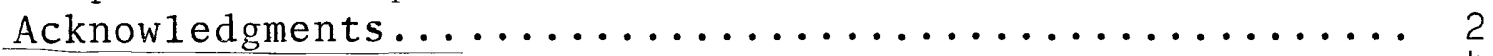

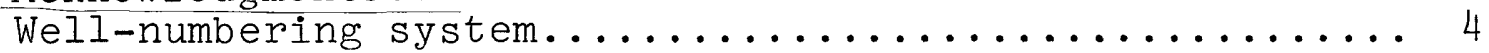

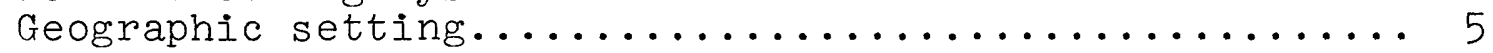

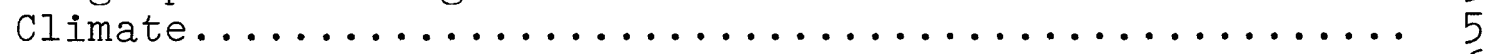

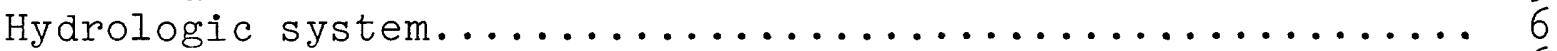

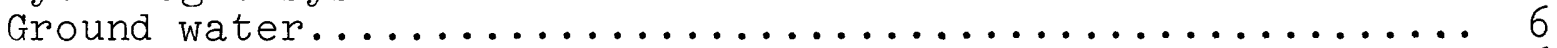

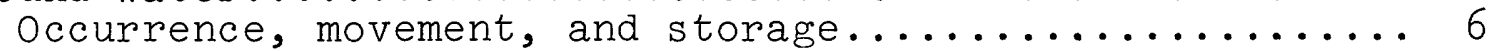

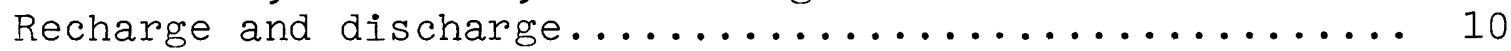

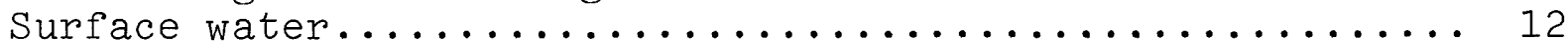

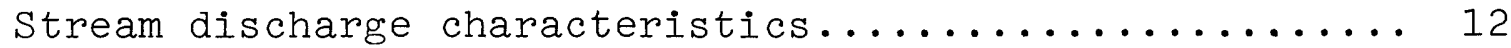

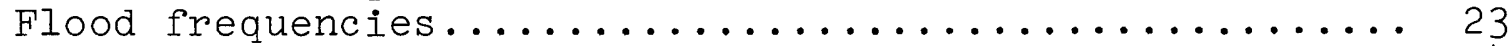

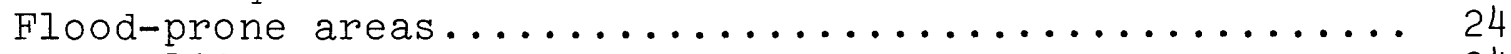

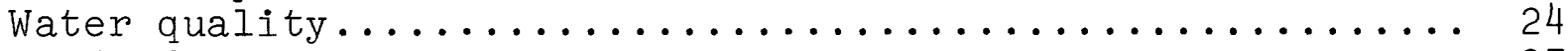

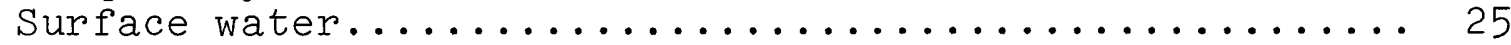

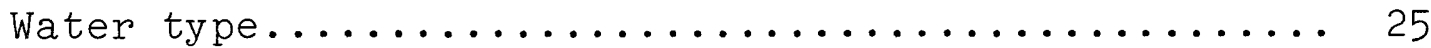

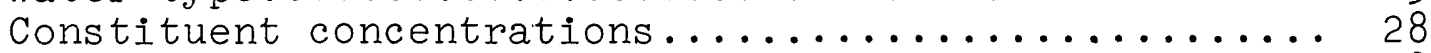

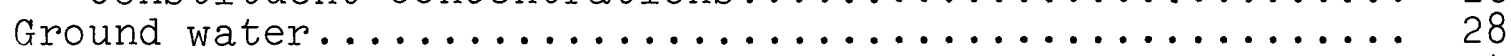

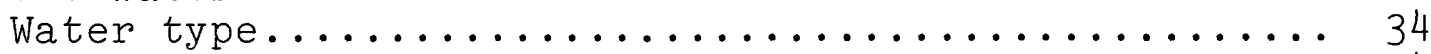

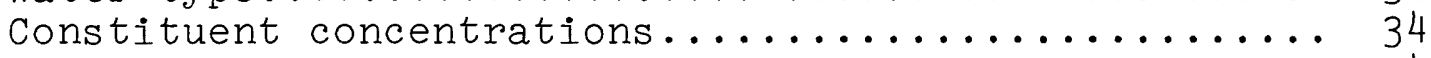

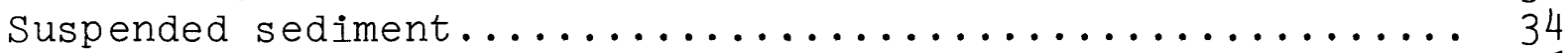

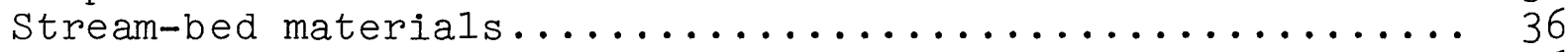

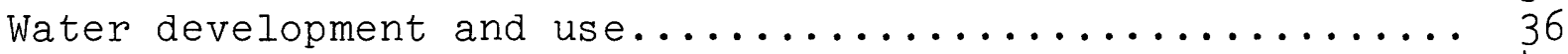

Potential hydrologic effects of strip mining........... 43

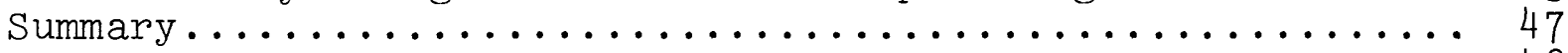

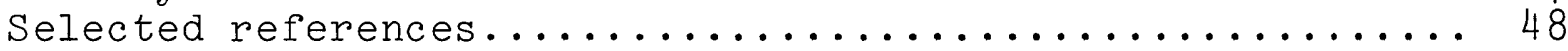

\section{ILLUSTRATIONS \\ (Plates are in pocket)}

Plate 1. Geologic map of the Blocker area, Pittsburg County, Oklahoma

2. Potentiometric map and locations of data collection sites in the Blocker area, Pittsburg County, Oklahoma

3. Map showing flood-prone areas in the Blocker area, Pittsburg County, Oklahoma 


\section{ILLUSTRATIONS (continued)}

Page

Figure 1. Map showing location of the Blocker area....... 3

2. Water-level hydrograph of well 07N-16E-24 BAB 1 as related to precipitation................. 11

3. Flow duration curve of Blue Creek........... 20

4. Discharge of Blue Creek in response to rainfall on March 23-24 and May 20-22, 1978.......... 21

5. Trilinear diagram for water from streams........ 26

6. Graphs showing specific conductance versus anion ratios of stream waters................ 27

7. Trilinear diagram for water from selected wells.. 35

8. Graphs showing relationship between stream discharge and suspended sediment discharge...... 37

9. Schematic cross sections showing stages in surface mining coal.................... 44

\section{TABLES}



2. Discharge of Blue Creek near Blocker, Okla.,

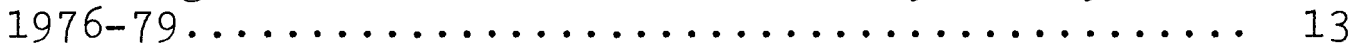

3. Discharge of Blue Creek tributary near Blocker, Okla., 1978-79....................... 17

4. Discharge of Mathuldy Creek near Crowder, Okla.,



5. Precipitation in the Blocker area and discharge

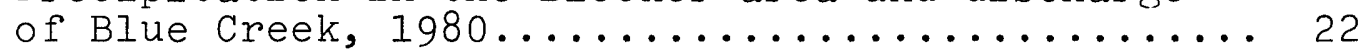

6-8. Mean, minimum, and maximum values for selected physical properties and chemical constituents of water from:



7. Blue Creek tributary................ 30

8. Mathuldy Creek.................... 31

9. Quality of water from selected wells.......... 32

10. Summary of suspended sediment data........... 38

11-13. Suspended sediment data for:

11. Blue Creek....................... 39

12. Blue Creek tributary................. 40

13. Mathuldy Creek.................... 41

14. Selected trace constituents and nutrients in stream bottom materials.................. 42 


\section{PRELIMINARY APPRAISAL OF THE HYDROLOGY OF THE BLOCKER AREA, PITTSBURG COUNTY, OKLAHOMA}

By

Melvin V. Marcher, DeRoy L. Bergman, Jerry D. Stoner, and Stephen P. Blumer

\section{ABSTRACT}

Bedrock in the Blocker area of southeastern 0klahoma consists principally of shale, siltstone, and sandstone of the Boggy and Savanna Formations of Pennsylvanian age. These rocks have been folded to form the Panther Mountain syncline on the south and the Kinta anticline on the north. Alluvium along streams is less than 15 feet thick and consists mainly of sandy silt.

Water in bedrock is under artesian conditions. Well depths range from 11 to 213 feet and average 75 feet. In 86 percent of the wells measured, the water level was less than 30 feet below the land surface. Because the rocks have minimal permeability, well yields probably are less than 5 gallons per minute. Ground water is commonly a mixed cation bicarbonate type with dissolved solids ranging from about 300 to 2,000 milligrams per liter. No relationship between water chemistry and well depth or geographic distribution is apparent.

Streams in the area are ephemeral and there are extended periods of no flow. Blue Creek was dry 30 percent of the time during 1976-80 and had flows of less than 0.1 cubic foot per second for at least 90 consecutive days. Stream water is generally a mixed cation sulfate type. The maximum dissolved-solids concentration determined in stream water was 360 milligrams per liter. Maximum suspended sediment discharge, in tons per day, was about 235 for Blue Creek, 40 for Blue Creek tributary, and 630 for Mathuldy Creek. Silt-clay particles (diameters less than 0.062 millimeter) are the dominant sediment size.

Potential hydrologic effects of strip mining for coal include: (1) creation of additional water storage in surface-mine ponds, (2) changes in rock permeability and ground-water storage, (3) changes in runoff and streamflow characteristics, (4) changes in drainage patterns, and (5) changes in the chemical quality and sediment loads of streams. 


\section{INTRODUCTION}

\section{Purpose and Scope}

The U.S. Bureau of Land Management is charged with the responsibility of assessing the probable water-resources impacts and reclamation capabilities of any area under Federal jurisdiction where coal might be mined by surface methods. To meet this responsibility, the EMRIA (Energy Minerals Rehabilitation Inventory and Analysis) program was developed and, as part of this program, the U.S. Geological Survey was requested to collect and analyze hydrologic data for selected areas in eastern Oklahoma that have potential for surface mining of coal. One such area is in the vicinity of the town of Blocker in northeastern Pittsburg County (fig. 1). In this area, the Secor Coal, which is about $3 \mathrm{ft}$ thick, is at or near the surface and thus amenable to strip mining.

The purpose of this report is to describe the hydrology of the Blocker area and describe some of the potential hydrologic changes that may occur as the result of strip mining based mainly on the data available as of 0ctober 1979. These data include: (1) continuous discharge data and analyses of periodic samples for chemical quality and sediment for Blue Creek, (2) partial-record discharge data and analyses of periodic samples for chemical quality and sediment for a tributary of Blue Creek and for Mathuldy Creek, (3) continuous record of the water level in one well, (4) records of 103 wells including onsite determinations of specific conductance and $\mathrm{pH}$ of water from 90 wells, (5) chemical analyses of water samples from 9 wells, and (6) records of precipitation at 3 sites.

Information on the geology of the area, as related to ground water, is taken from a report by Dane, Rothrock, and Williams (1938) supplemented with onsite field observations, logs of cores from test holes drilled by the Bureau of Reclamation under contract to the Bureau of Land Management, and auger test holes drilled by the U.S. Geological Survey. Information on soils is provided in a report by Shingleton (1971). Climatic data are summarized by Holbrook (1971).

\section{Acknowledgments}

Appreciation is extended to residents of the area who provided information about their wells and permitted measurements of water levels and collection of water samples. Jerry W. Mathiews, District Conservationist, Soil Conservation Service, U.S. Department of Agriculture, provided useful information on farm ponds and general soil conditions in the area. 

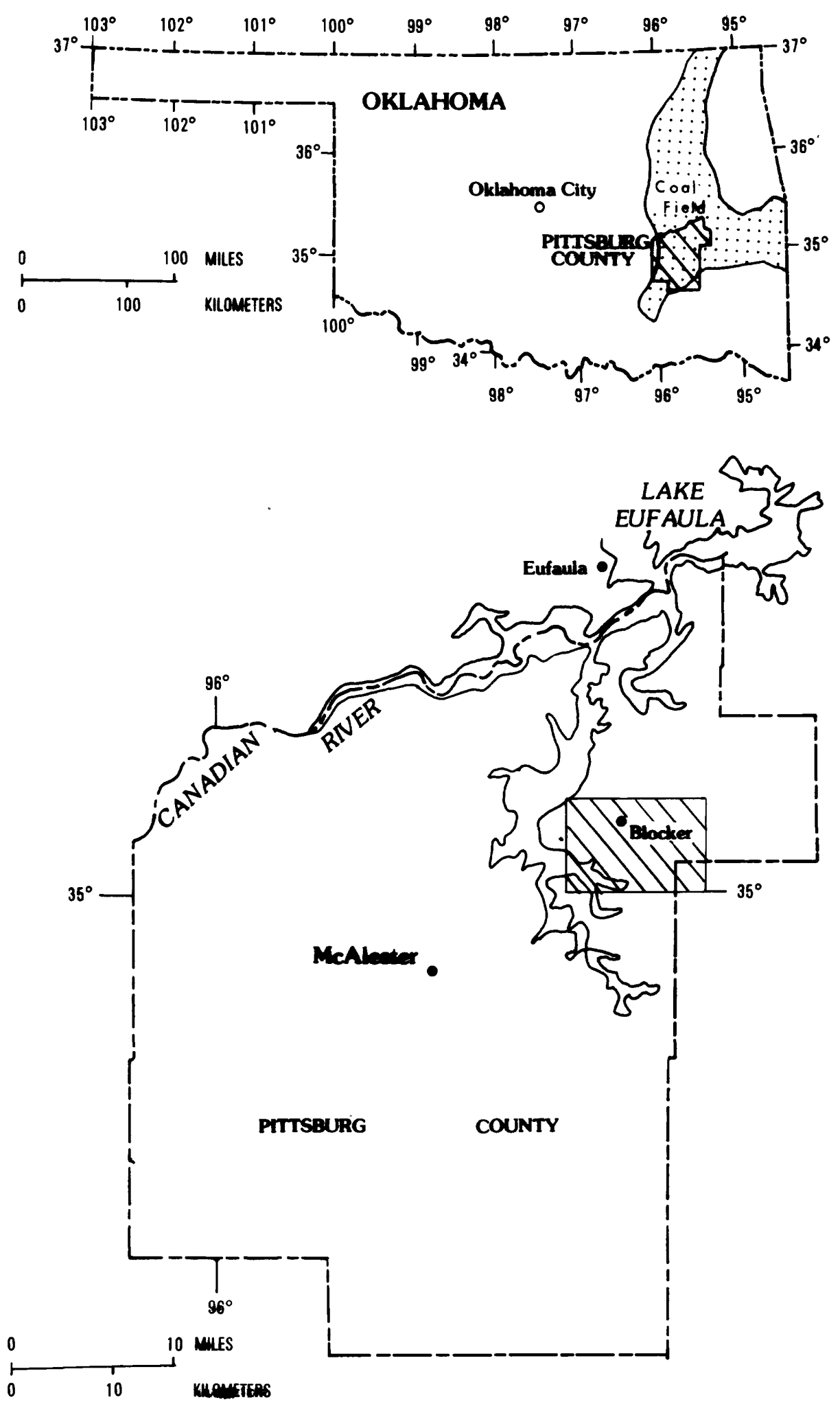

Figure 1-Location of the Blockar area. 


\section{Well-Numbering System}

The standard method of describing the location of wells by fractional section, section, township, and range is replaced by the method illustrated in the diagram below. The location of the well indicated by the dot commonly would be described as NW 1/4, NE 1/4, NE 1/4, sec. 8, T. 8 N., R. 25 E. By the method used in this report, quarter subdivisions of the section are indicated by letters and the location of the well is given as $08 \mathrm{~N}-25 \mathrm{E}-08 \mathrm{AAB} 1$. The final digit (1) is the sequential number of a well within the smallest fractional subdivision.






\section{Geographic Setting}

The Blocker area lies in the McAlester marginal hills geomorphic province (Johnson and others, 1972) and is in the Arkoma geologic basin. In this area, the rocks have been moderately folded to form east-west trending anticlines and synclines. The landscape is characterized by irregular hills and ridges generally capped by erosionresistant sandstones and covered with scrubby trees and brush. The intervening broad valleys have been formed by weathering and erosion of thick, weakly-resistant shales and are vegetated with native grasses, shrubs, wild flowers, and weeds.

\section{Climate}

The area has a warm, temperate, continental climate (Holbrook, 1971). Spring and fall months are usually mild and the summers are long and hot. Based on records at McAlester and Eufaula, the nearest weather stations, annual precipitation is estimated to be 42 in. Most precipitation falls as rain during short, intense thunderstorms. About 32 percent of the precipitation falls in the spring, 27 percent in the summer, 22 percent in the fall, and 19 percent in the winter (Holbrook, 1971). Based on records for 1931-60, on the long-term average, 1 year in 10 will have less than 29 in. of precipitation and 1 year in 10 will have more than 53 in. Average annual lake evaporation is about $53 \mathrm{in}$. 


\section{HYDROLOGIC SYSTEM}

On the precipitation falling on a given area some runs quickly as streamflow and some percolates into the soil. The relative proportions of water that runs off to that which infiltrates the soil depends on the form, intensity, and duration of precipitation, slope of the land surface, permeability of the soil, character and amount of vegetation, antecedent soil moisture, and climatic conditions. Precipitation entering the soil first replaces previously depleted soil moisture. Water in excess of that needed to replace soil moisture percolates downward into the zone of saturation to become ground-water recharge. Water retained in the soil is eventually evaporated or transpired by plants.

During dry periods, streamflow is sustained by ground-water discharge if it is available. Bedrock in the 0klahoma coal field has minimal porosity and permeability and, therefore, a minimal storage capacity. Alluvium along the streams generally should be capable of storing considerable amounts of water. However, in most of the coal field, alluvium is of limited areal extent, is generally less than 15 $\mathrm{ft}$ thick, and consists mainly of silt and clay which retain most of the water by capillary action. As a consequence of these geologic conditions, and because the stream channels are above the water table, most streams in the $0 \mathrm{klahoma}$ coal field with drainage areas less than $50 \mathrm{mi}^{2}$ go dry during parts of most years.

\section{GROUND WATER}

Occurrence, Movement, and Storage

The occurrence, movement, and storage of ground water in the Blocker area is largely controlled by the lateral and vertical distribution of rock units and their physical characteristics, especially permeability, and by the geologic structure.

Bedrock consists principally of shale with widely separated sandstone units of the Boggy and Savanna Formations (pl. 1); most wells obtain water from the Boggy Formation (table 1). Core-drill holes, auger holes, and onsite observations show that much of the shale is thinly laminated and silty and includes beds of shaly sandstone. Sandstone units, which make up about 25 percent of the total thickness of exposed rocks, actually consist of interbedded sandstone, shale, and siltstone. For example, the log of core-drill hole $07 \mathrm{~N}-17 \mathrm{E}-30$ DDD 1 shows that the sandstone unit capping Blue Mountain is about one-fourth sandstone, one-fourth siltstone, and one-half shale. Layers of sandstone are fine grained, well cemented with silica and iron oxide, and contain beds of shale a few inches to several feet thick. 
Table 1.--Records of wells.

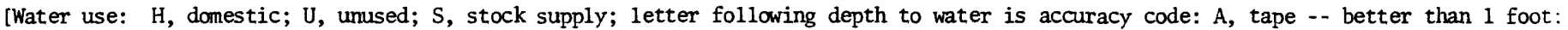
G, reported; aquifer: Pb, Boggy Formation; Ps, Savanna Formation; remarks: Q, chemical analysis given in table 9; ft = feet; in = inch; Mo-Yr = month-year; micramhos = micranhos per centimeter at $25^{\circ}$ Celsius $]$

\begin{tabular}{|c|c|c|c|c|c|c|c|c|c|c|c|}
\hline $\begin{array}{c}\text { Well } \\
\text { location }\end{array}$ & $\begin{array}{c}\text { Owner } \\
\text { or } \\
\text { user }\end{array}$ & $\begin{array}{l}\text { Wel1 } \\
\text { depth } \\
\text { (ft) }\end{array}$ & $\begin{array}{c}\text { Water } \\
\text { use }\end{array}$ & $\begin{array}{c}\text { Well } \\
\text { diameter } \\
\text { (in) }\end{array}$ & $\begin{array}{l}\text { Depth } \\
\text { to } \\
\text { water } \\
(\mathrm{ft}) \\
\end{array}$ & $\begin{array}{c}\text { Date } \\
\text { measured } \\
(\mathrm{Mo}-\mathrm{Yr})\end{array}$ & Aquifer & $\begin{array}{l}\text { Altitude } \\
\text { of land } \\
\text { surface } \\
\text { (ft) }\end{array}$ & $\begin{array}{c}\text { Specific } \\
\text { conductance } \\
\text { (micromhos) }\end{array}$ & $\underset{\text { (units) }}{\mathrm{pHi}}$ & Remarks \\
\hline $06 \mathrm{~N}-16 \mathrm{E}-01 \mathrm{CBC} 1$ & Mason, willard & $-\cdots$ & $\mathrm{H}$ & -- & $39 \mathrm{~A}$ & $5-76$ & $\mathrm{~Pb}$ & -- & 1,770 & 6.7 & \\
\hline $06 \mathrm{~N}-16 \mathrm{E}-01$ DAD 1 & Davis, Lee & 41 & $\mathrm{H}$ & 6 & $15 \mathrm{~A}$ & $5-76$ & $\mathrm{~Pb}$ & 630 & -. - & $\cdots$ & \\
\hline $06 \mathrm{~N}-16 \mathrm{E}-01$ DDA 1 & Davis, Lee & 74 & $\mathrm{H}$ & 6 & $17 \mathrm{~A}$ & $5-76$ & $\mathrm{~Pb}$ & 622 & 860 & 6.8 & $\mathrm{Q}$ \\
\hline $06 \mathrm{~N}-16 \mathrm{E}-02$ BBC 1 & Hilbert, Wallace & 87 & $\mathrm{H}$ & --- & $16 \mathrm{G}$ & $6-76$ & $\mathrm{~Pb}$ & 616 & 3,490 & 6.8 & \\
\hline $06 \mathrm{~N}-16 \mathrm{E}-02 \mathrm{BBC} 2$ & Summer lin, C. & 103 & $\mathrm{H}$ & 6 & $52 \mathrm{~A}$ & $5-76$ & $\mathrm{~Pb}$ & 618 & 6,500 & 7.2 & \\
\hline $06 \mathrm{~N}-16 \mathrm{E}-02 \mathrm{BBC} 3$ & Davis, Walter & 120 & $\mathrm{H}$ & 6 & $33 \mathrm{~A}$ & $6-76$ & $\mathrm{~Pb}$ & 621 & 1,820 & 8.7 & \\
\hline $06 \mathrm{~N}-16 \mathrm{E}-02$ BBD 1 & Hilbert, Wallace & 72 & $\mathrm{U}$ & 6 & $14 \mathrm{~A}$ & $6-76$ & $\mathrm{~Pb}$ & 619 & $\ldots$ & $\cdots$ & \\
\hline $06 \mathrm{~N}-16 \mathrm{E}-02$ BCB 1 & Reed, Richard & 67 & $\mathrm{H}$ & 4 & $41 \mathrm{~A}$ & $6-76$ & $\mathrm{~Pb}$ & 609 & 2,630 & 8.8 & \\
\hline $06 \mathrm{~N}-16 \mathrm{E}-02$ BCB 2 & Reed, Richard & 54 & $\mathrm{U}$ & 4 & $31 \mathrm{~A}$ & $6-76$ & $\mathrm{~Pb}$ & 600 & $\ldots$ & --- & \\
\hline $06 \mathrm{~N}-16 \mathrm{E}-03 \mathrm{ABB} 1$ & Hilbert, Wallace & 72 & $\mathrm{H}$ & 6 & $23 \mathrm{~A}$ & $6-76$ & $\mathrm{~Pb}$ & 621 & 1,330 & 6.9 & \\
\hline $06 \mathrm{~N}-16 \mathrm{E}-03 \mathrm{ABC} 1$ & Skellenger, E. & 57 & $\mathrm{U}$ & 6 & $15 \mathrm{~A}$ & $6-76$ & $\mathrm{~Pb}$ & 610 & -- & -- & \\
\hline $06 \mathrm{~N}-17 \mathrm{E}-05$ BDA 1 & Unknown & 85 & $\mathrm{H}$ & 6 & $34 \mathrm{~A}$ & $5-76$ & $\mathrm{~Pb}$ & 659 & --- & -- & \\
\hline $06 \mathrm{~N}-17 \mathrm{E}-05$ BDD 1 & Cabshaw, Jarold & 68 & $\mathrm{H}$ & 6 & $28 \mathrm{~A}$ & $5-76$ & $\mathrm{~Pb}$ & 650 & 1,470 & 7.0 & \\
\hline $06 \mathrm{~N}-17 \mathrm{E}-05 \mathrm{CBB} 1$ & Unknown & 77 & $\mathrm{U}$ & 6 & $8 \mathrm{~A}$ & $5-76$ & $\mathrm{~Pb}$ & 639 & 2,680 & 6.7 & \\
\hline $06 \mathrm{~N}-17 \mathrm{E}-05 \mathrm{DBB} 1$ & Smith, Marine & 100 & $\mathrm{H}$ & 6 & $15 \mathrm{~A}$ & $5-76$ & $\mathrm{~Pb}$ & 619 & 1,930 & 8.0 & \\
\hline $06 \mathrm{~N}-17 \mathrm{E}-06 \mathrm{CAC} 1$ & Hooks, J.D. & 83 & $\mathrm{H}$ & 6 & $31 \mathrm{~A}$ & $5-76$ & $\mathrm{~Pb}$ & 639 & -- & -- & \\
\hline $06 \mathrm{~N}-17 \mathrm{E}-06$ CCC 1 & Cockerhan, David & 73 & $\mathrm{H}$ & 6 & $21 \mathrm{~A}$ & $5-76$ & $\mathrm{~Pb}$ & 606 & 1,240 & 6.8 & \\
\hline $06 \mathrm{~N}-17 \mathrm{E}-06 \mathrm{CCC} 2$ & Hooks, Lena & 74 & $\mathrm{H}$ & 6 & $24 \mathrm{~A}$ & $5-76$ & $\mathrm{~Pb}$ & 610 & 1,550 & 7.2 & \\
\hline $06 \mathrm{~N}-17 \mathrm{E}-06$ DBA 1 & Sharp, Don & 95 & $\mathrm{H}$ & 6 & $31 \mathrm{~A}$ & $5-76$ & $\mathrm{~Pb}$ & 641 & 2,750 & 7.3 & \\
\hline $06 \mathrm{~N}-17 \mathrm{E}-06 \mathrm{DCA} 1$ & Unknown & 46 & $\mathrm{U}$ & 5 & $17 \mathrm{~A}$ & $5-76$ & $\mathrm{~Pb}$ & 618 & 1,060 & 7.2 & \\
\hline $07 \mathrm{~N}-16 \mathrm{E}-13$ DCB 1 & Allen, Raymond & 92 & $\mathrm{H}$ & 6 & $33 \mathrm{~A}$ & $6-76$ & $\mathrm{~Pb}$ & 700 & 1,140 & 6.0 & \\
\hline $07 \mathrm{~N}-16 \mathrm{E}-13 \mathrm{DCB} 2$ & Allen, Raymond & 123 & $\mathrm{H}$ & 6 & $13 \mathrm{~A}$ & $6-76$ & $\mathrm{~Pb}$ & 699 & 1,340 & 6.5 & $Q$ \\
\hline $07 \mathrm{~N}-16 \mathrm{E}-14$ DDD 1 & Allen, Larry & 85 & $\mathrm{H}$ & 6 & $15 \mathrm{~A}$ & $6-76$ & $\mathrm{~Pb}$ & 659 & 910 & 7.4 & \\
\hline $07 \mathrm{~N}-16 \mathrm{E}-15 \mathrm{CBC} 1$ & Flud, Roy & -- & $\mathrm{H}$ & 6 & -- & -- & $\mathrm{Pb}$ & 602 & 1,280 & 8.4 & \\
\hline $07 \mathrm{~N}-16 \mathrm{E}-22$ ADD 1 & Randal, O.A. & 37 & $\mathrm{H}$ & 6 & $2 \mathrm{~A}$ & $6-76$ & $\mathrm{~Pb}$ & 630 & 160 & 5.9 & \\
\hline $07 \mathrm{~N}-16 \mathrm{E}-22$ ADD 2 & Randa1, O.A. & 100 & $\mathrm{H}$ & 6 & $6 \mathrm{~A}$ & $6-76$ & $\mathrm{~Pb}$ & 628 & 340 & 7.1 & \\
\hline $07 \mathrm{~N}-16 \mathrm{E}-22$ BBB 1 & Wood, Hollis & 50 & $\mathrm{H}$ & 6 & $25 \mathrm{~A}$ & $6-76$ & $\mathrm{~Pb}$ & 605 & 1,390 & 8.4 & \\
\hline $07 \mathrm{~N}-16 \mathrm{~N}-23$ AAD 1 & Allen, Darrel1 & 114 & $\mathrm{H}$ & 6 & $6 \mathrm{~A}$ & $6-76$ & $\mathrm{~Pb}$ & 654 & 1,490 & 8.3 & \\
\hline $07 \mathrm{~N}-16 \mathrm{E}-23 \mathrm{CBB} 1$ & Brown, Gene & 62 & $\mathrm{H}$ & 6 & $8 \mathrm{~A}$ & $6-76$ & $\mathrm{~Pb}$ & 630 & 1,950 & 7.9 & \\
\hline $07 \mathrm{~N}-16 \mathrm{E}-23 \mathrm{CBB} 2$ & Powe11, Jim & 65 & $\mathrm{H}$ & 6 & $20 \mathrm{~A}$ & $6-76$ & $\mathrm{~Pb}$ & 621 & 430 & 6.8 & $Q$ \\
\hline $07 \mathrm{~N}-16 \mathrm{E}-24$ ABA 1 & Allen, Thomas & 46 & $\mathrm{H}$ & 6 & $10 \mathrm{~A}$ & $6-76$ & $\mathrm{~Pb}$ & 663 & 525 & 6.7 & \\
\hline $07 \mathrm{~N}-16 \mathrm{E}-24$ ABD 1 & Hooks, Claty & 68 & $\mathrm{H}$ & 6 & $20 \mathrm{~A}$ & $6-76$ & $\mathrm{~Pb}$ & 663 & 370 & 6.5 & \\
\hline $07 \mathrm{~N}-16 \mathrm{E}-24$ ACA 1 & Shannon, Nadine & 40 & $\mathrm{H}$ & 6 & $4 \mathrm{~A}$ & $6-76$ & $\mathrm{~Pb}$ & 661 & 270 & 6.3 & \\
\hline $07 \mathrm{~N}-16 \mathrm{E}-24$ ACA 2 & Shamon, Nadine & 37 & $\mathrm{U}$ & 6 & $11 \mathrm{~A}$ & $6-76$ & $\mathrm{~Pb}$ & 650 & $\cdots$ & $\cdots$ & \\
\hline $07 \mathrm{~N}-16 \mathrm{E}-24$ BAB 1 & Suddreth, Sam & 63 & $\mathrm{U}$ & 10 & $28 \mathrm{~A}$ & $6-76$ & $\mathrm{~Pb}$ & 682 & 215 & 6.3 & \\
\hline $07 \mathrm{~N}-16 \mathrm{E}-24 \mathrm{CAA} 1$ & Gray, G. C. & 100 & $\mathrm{H}$ &.- & -- & $6-76$ & $\mathrm{~Pb}$ & 661 & 660 & 6.6 & \\
\hline $07 \mathrm{~N}-16 \mathrm{E}-24 \mathrm{CAB} 1$ & Blocker School & 49 & $\mathrm{U}$ & 6 & $20 \mathrm{~A}$ & $6-76$ & $\mathrm{~Pb}$ & 663 & 1,330 & 6.6 & \\
\hline $07 \mathrm{~N}-16 \mathrm{E}-24 \mathrm{CAD} 1$ & Lee, Lona M. & 44 & $\mathrm{H}$ & 8 & $14 \mathrm{~A}$ & $6-76$ & $\mathrm{~Pb}$ & 647 & 425 & 6.5 & \\
\hline $07 \mathrm{~N}-16 \mathrm{E}-24 \mathrm{CDC} 1$ & Duff, Michael H. & 74 & $\mathrm{H}$ & 6 & $14 \mathrm{~A}$ & $6-76$ & $\mathrm{~Pb}$ & 655 & 1,350 & 7.0 & \\
\hline $07 \mathrm{~N}-16 \mathrm{E}-24 \mathrm{CDC} 2$ & Rumbaugh, George & 18 & $\mathrm{H}$ & 18 & $8 \mathrm{~A}$ & $6-76$ & $\mathrm{~Pb}$ & 655 & 1,270 & 6.6 & \\
\hline $07 \mathrm{~N}-16 \mathrm{E}-24 \mathrm{CDD} 1$ & Duff, Norwood & 28 & $\mathrm{H}$ & 6 & $9 \mathrm{~A}$ & $6-76$ & $\mathrm{~Pb}$ & 639 & 1,900 & 6.5 & \\
\hline $07 \mathrm{~N}-16 \mathrm{E}-24 \mathrm{CDD} 2$ & Duff, Norwood & 39 & $\mathrm{H}$ & 6 & $5 \mathrm{~A}$ & $6-76$ & $\mathrm{~Pb}$ & 639 & 1,220 & $6 . b$ & \\
\hline $07 \mathrm{~N}-16 \mathrm{E}-24 \mathrm{DAB} 1$ & Holman, Bob & 142 & $\mathrm{~S}$ & 6 & $4 \mathrm{~A}$ & $6-76$ & $\mathrm{~Pb}$ & 649 & 925 & 8.1 & \\
\hline $07 \mathrm{~N}-16 \mathrm{E}-24 \mathrm{DAC} 1$ & Brock, Leroy & 75 & $\mathrm{H}$ & 10 & $15 \mathrm{~A}$ & $6-76$ & $\mathrm{~Pb}$ & 649 & 500 & 6.5 & \\
\hline $07 \mathrm{~N}-16 \mathrm{E}-24$ DAC 2 & Brock, Leroy & 213 & $\mathrm{H}$ & 8 & $18 \mathrm{~A}$ & $6-76$ & $\mathrm{~Pb}$ & 641 & 530 & 6.9 & \\
\hline $07 \mathrm{~N}-16 \mathrm{E}-24 \mathrm{DAD} 1$ & Shamnon, Bud & 96 & $\mathrm{H}$ & 6 & $10 \mathrm{~A}$ & $6-76$ & $\mathrm{~Pb}$ & 631 & 835 & 6.1 & \\
\hline $07 \mathrm{~N}-16 \mathrm{E}-24$ DBA 1 & Trollinger, C. & 120 & $\mathrm{H}$ & 6 & $16 \mathrm{~A}$ & $6-76$ & $\mathrm{~Pb}$ & 661 & 610 & 6.8 & \\
\hline $07 \mathrm{~N}-16 \mathrm{E}-24 \mathrm{DBA} 2$ & Holman, Bob & 124 & $\mathrm{H}$ & 6 & $19 \mathrm{~A}$ & $6-76$ & $\mathrm{~Pb}$ & 660 & 1,120 & 7.4 & \\
\hline $07 \mathrm{~N}-16 \mathrm{E}-24$ DBA 3 & Michael, Charles & 102 & $\mathrm{H}$ & 6 & $17 \mathrm{~A}$ & $6-76$ & $\mathrm{~Pb}$ & 654 & 660 & 6.9 & \\
\hline $07 \mathrm{~N}-16 \mathrm{E}-24 \mathrm{DBA} 4$ & Waldrop, Mattie & 90 & $\mathrm{H}$ & 6 & $26 \mathrm{~A}$ & $6-76$ & $\mathrm{~Pb}$ & 670 & 1,140 & 7.2 & \\
\hline
\end{tabular}


Tab1e 1.--Records of wells---Continued

\begin{tabular}{|c|c|c|c|c|c|c|c|c|c|c|c|}
\hline $\begin{array}{c}\text { Well } \\
\text { location }\end{array}$ & $\begin{array}{l}\text { Owner } \\
\text { or } \\
\text { user }\end{array}$ & $\begin{array}{l}\text { Well } \\
\text { depth } \\
(f t)\end{array}$ & $\begin{array}{l}\text { Water } \\
\text { use }\end{array}$ & $\begin{array}{l}\text { We11 } \\
\text { diameter } \\
\text { (in) }\end{array}$ & $\begin{array}{l}\text { Depth } \\
\text { to } \\
\text { water } \\
\text { (ft) }\end{array}$ & $\begin{array}{c}\text { Date } \\
\text { measured } \\
(\text { Mo-Yr) }\end{array}$ & Aquifer & $\begin{array}{l}\text { Altitude } \\
\text { of land } \\
\text { surface } \\
(f t)\end{array}$ & $\begin{array}{l}\text { Specific } \\
\text { conductance } \\
\text { (micramhos) }\end{array}$ & $\underset{\text { (units) }}{\mathrm{pH}}$ & Remarks \\
\hline $07 \mathrm{~N}-16 \mathrm{E}-24$ DBB 1 & Bush, Martin & 84 & $\mathrm{H}$ & 6 & $25 \mathrm{~A}$ & $6-76$ & $\mathrm{~Pb}$ & 669 & 7.50 & 7.0 & \\
\hline $07 \mathrm{~N}-16 \mathrm{E}-24$ DBB 2 & Brock, Delmar & 37 & $\mathrm{U}$ & 6 & $12 \mathrm{~A}$ & $6-76$ & $\mathrm{~Pb}$ & 660 &.-- & -- & \\
\hline $07 \mathrm{~N}-16 \mathrm{E}-24 \mathrm{DBB} 3$ & Brock, Delmar & 75 & $\mathrm{H}$ & 6 & -.- & -- & $\mathrm{Pb}$ & 662 & 540 & 6.2 & \\
\hline $07 \mathrm{~N}-16 \mathrm{E}-24$ DBB 4 & Allen, Lillian &.- & $\mathrm{H}$ & --- & -- & -.- & $\mathrm{Pb}$ & 657 & 665 & 7.2 & \\
\hline $07 \mathrm{~N}-16 \mathrm{E}-24 \mathrm{DBC} 1$ & Danie1, John & 40 & $\mathrm{U}$ & 6 & $13 \mathrm{~A}$ & $6-76$ & $\mathrm{~Pb}$ & 641 & 435 & 5.8 & \\
\hline $07 \mathrm{~N}-16 \mathrm{E}-24 \mathrm{DBC} 2$ & Daniel, John & 96 & $\mathrm{H}$ & 6 & $4 \mathrm{~A}$ & $6-76$ & $\mathrm{~Pb}$ & 648 & 1,200 & 7.1 & \\
\hline $07 \mathrm{~N}-16 \mathrm{E}-24-\mathrm{DBC} 3$ & Morrow, A.J. & 54 & $\mathrm{H}$ & 6 & $4 \mathrm{~A}$ & $6-76$ & $\mathrm{~Pb}$ & 644 & 1,150 & 7.7 & \\
\hline $07 \mathrm{~N}-16 \mathrm{E}-24 \mathrm{DBC} 4$ & Morrow, A.J. & 11 & $\mathrm{U}$ & 6 & $4 \mathrm{~A}$ & $6-76$ & $\mathrm{~Pb}$ & 648 & 410 & 6.8 & \\
\hline $07 \mathrm{~N}-16 \mathrm{E}-24 \mathrm{DBC} 5$ & Morrow, A.J. & 25 & $\mathrm{U}$ & --- & $1 \mathrm{~A}$ & $6-76$ & $\mathrm{~Pb}$ & 649 & 260 & 6.1 & \\
\hline $07 \mathrm{~N}-16 \mathrm{E}-24$ DBD 1 & Trolinger, Ida & 67 & $\mathrm{H}$ & 6 & $19 \mathrm{~A}$ & $6-76$ & $\mathrm{~Pb}$ & 650 & 470 & 6.9 & \\
\hline $07 \mathrm{~N}-16 \mathrm{E}-24$ DBD 2 & Trolinger, Wilma & 23 & $\mathrm{H}$ & 24 & $4 \mathrm{~A}$ & $6-76$ & $\mathrm{~Pb}$ & 655 & 270 & 6.2 & \\
\hline $07 \mathrm{~N}-16 \mathrm{E}-24$ DBD 3 & Shannon, L.C. & 76 & $\mathrm{H}$ & 6 & $21 \mathrm{~A}$ & $6-76$ & $\mathrm{~Pb}$ & 653 & 550 & 7.3 & \\
\hline $07 N-16 \mathrm{E}-24 \mathrm{DCC} 1$ & Duff, Norwood & 27 & $\mathrm{H}$ & 6 & $6 \mathrm{~A}$ & $6-76$ & $\mathrm{~Pb}$ & 635 & 1,560 & 6.5 & \\
\hline $07 \mathrm{~N}-16 \mathrm{E}-24 \mathrm{DCC} 2$ & Duff, Norwood & 71 & $\mathrm{H}$ & 6 & $11 \mathrm{~A}$ & $6-76$ & $\mathrm{~Pb}$ & 639 & 1,200 & 6.6 & \\
\hline $07 \mathrm{~N}-16 \mathrm{E}-25$ AAA 1 & Mann, Mary & 66 & $\mathrm{H}$ & 6 & $2 \mathrm{~A}$ & $5-76$ & $\mathrm{~Pb}$ & 640 & 500 & 7.1 & \\
\hline $07 \mathrm{~N}-16 \mathrm{E}-25$ AAA 2 & Mann, Mary & 70 & $\mathrm{U}$ & --- & $1 \mathrm{~A}$ & $6-76$ & $\mathrm{~Pb}$ & 637 & --- & $--\cdot$ & \\
\hline $07 \mathrm{~N}-16 \mathrm{E}-25$ ACB 1 & Cheney, Ethe1 & 44 & $\mathrm{H}$ & 6 & $23 \mathrm{~A}$ & 6-76 & $\mathrm{Pb}$ & 660 & 190 & 6.0 & \\
\hline $07 \mathrm{~N}-16 \mathrm{E}-25 \mathrm{ACC} 1$ & Weiher, Allen & 72 & $\mathrm{H}$ & 6 & $17 \mathrm{~A}$ & $5-76$ & $\mathrm{~Pb}$ & 635 & 400 & 8.6 & Q \\
\hline $07 \mathrm{~N}-16 \mathrm{E}-25$ BAA 1 & Andsley, Erman & 97 & $\mathrm{H}$ & 6 & $12 \mathrm{~A}$ & $6-76$ & $\mathrm{~Pb}$ & 636 & 850 & 7.5 & $Q$ \\
\hline $07 \mathrm{~N}-16 \mathrm{E}-25 \mathrm{BDA} 1$ & Allen, Jesse & 85 & $\mathrm{H}$ & 6 & $15 \mathrm{~A}$ & $6-76$ & $\mathrm{~Pb}$ & 660 & 610 & --- & \\
\hline $07 \mathrm{~N}-16 \mathrm{E}-25$ BDA 2 & Blocker Baptist & 64 & $\mathrm{H}$ & 6 & $14 \mathrm{~A}$ & $6-76$ & $\mathrm{~Pb}$ & 665 & --- & --- & \\
\hline $07 \mathrm{~N}-16 \mathrm{E}-25 \mathrm{CAD} 1$ & Williams, Thomas & 104 & $\mathrm{H}$ & 6 & $12 \mathrm{~A}$ & $6-76$ & $\mathrm{~Pb}$ & 618 & 1,860 & 8.8 & \\
\hline $07 \mathrm{~N}-16 \mathrm{E}-26$ AAA 1 & Stackhouse, Floyd & 31 & $\mathrm{H}$ & 24 & $7 \mathrm{~A}$ & $6-76$ & $\mathrm{~Pb}$ & 652 & 1,525 & 7.4 & \\
\hline $07 \mathrm{~N}-16 \mathrm{E}-26$ ABA 1 & Lee, R.E. & 30 & $\mathrm{H}$ & 6 & $5 \mathrm{~A}$ & $6-76$ & $\mathrm{~Pb}$ & 652 & 2,900 & 7.1 & Q \\
\hline $07 \mathrm{~N}-16 \mathrm{E}-34 \mathrm{DCC} 1$ & McFarland P. & 164 & $\mathrm{U}$ & 6 & $26 \mathrm{~A}$ & $6-76$ & $\mathrm{~Pb}$ & 602 & $\cdots$ & -- & \\
\hline $07 \mathrm{~N}-16 \mathrm{E}-34$ DCC 2 & Henson, Lester & 122 & $\mathrm{H}$ & 6 & $38 \mathrm{~A}$ & $6-76$ & $\mathrm{~Pb}$ & 611 & 1,740 & 8.2 & \\
\hline $07 \mathrm{~N}-16 \mathrm{E}-34 \mathrm{DCD} 1$ & McFarland, $\mathrm{P}$. & 81 & $\mathrm{H}$ & 6 & $29 \mathrm{~A}$ & $6-76$ & $\mathrm{~Pb}$ & 588 & 1,100 & 7.5 & \\
\hline $07 \mathrm{~N}-16 \mathrm{E}-34$ CAC 1 & Davenport, W.A. & 74 & $\mathrm{U}$ & 6 & $46 \mathrm{~A}$ & $6-76$ & $\mathrm{~Pb}$ & 700 & 610 & 6.7 & \\
\hline $07 \mathrm{~N}-17 \mathrm{E}-16 \mathrm{DAB} 1$ & Davenport, W.A. & 57 & $\mathrm{H}$ & 6 & $17 \mathrm{~A}$ & $6-76$ & Po & 652 & 1,100 & 7.1 & \\
\hline $07 \mathrm{~N}-17 \mathrm{E}-17 \mathrm{CCC} 1$ & Davenport, Jimmy & 84 & $\mathrm{H}$ & 6 & $15 \mathrm{~A}$ & $6-76$ & $\mathrm{~Pb}$ & 681 & 660 & 6.4 & Q \\
\hline $07 \mathrm{~N}-17 \mathrm{E}-17 \mathrm{DDA} 1$ & Moody, Ivan & 87 & $\mathrm{H}$ & 6 & $45 \mathrm{~A}$ & $6-76$ & $\mathrm{~Pb}$ & 695 & 955 & 7.8 & \\
\hline $07 \mathrm{~N}-17 \mathrm{E}-17$ DDA 2 & Moody, Larry & 157 & $\mathrm{H}$ & 8 & $28 \mathrm{~A}$ & $6-76$ & $\mathrm{~Pb}$ & 720 & 850 & 8.0 & \\
\hline $07 \mathrm{~N}-17 \mathrm{E}-18 \mathrm{CCB} 1$ & Bristow, A.J. & 90 & $\mathrm{H}$ & 6 & $30 \mathrm{~A}$ & $6-76$ & $\mathrm{~Pb}$ & 703 & 740 & 7.6 & \\
\hline $07 \mathrm{~N}-17 \mathrm{E}-19$ ABB 1 & Davenport, $\mathrm{H}$. & 77 & $\mathrm{U}$ & 10 & $7 \mathrm{~A}$ & $6-76$ & $\mathrm{~Pb}$ & 681 & --- & $\cdots$ & \\
\hline $07 \mathrm{~N}-17 \mathrm{E}-19$ ABB 2 & Davenport, $\mathrm{H}$. & 80 & $\mathrm{H}$ & 6 & $9 \mathrm{~A}$ & $6-76$ & $\mathrm{~Pb}$ & 682 & --- & --- & \\
\hline $07 \mathrm{~N}-17 \mathrm{E}-19 \mathrm{CBC} 1$ & Unknown & 35 & $\mathrm{U}$ & 6 & $25 \mathrm{~A}$ & $6-76$ & $\mathrm{~Pb}$ & 641 & -.. & --- & \\
\hline $07 \mathrm{~N}-17 \mathrm{E}-19$ DDB 1 & Noble, Walter & 80 & $\mathrm{H}$ & 8 & $20 \mathrm{~A}$ & $6-76$ & $\mathrm{~Pb}$ & 670 & 800 & 6.8 & \\
\hline $07 N-17 \mathrm{E}-20$ AAA 1 & Holt, Jerry & 59 & $\mathrm{H}$ & 6 & $9 \mathrm{~A}$ & $6-76$ & $\mathrm{~Pb}$ & 675 & 1,290 & 7.3 & \\
\hline $07 \mathrm{~N}-17 \mathrm{E}-20 \mathrm{CCC} 1$ & Mendenhall, Ruth & 78 & $\mathrm{H}$ & 6 & $16 \mathrm{~A}$ & $5-76$ & $\mathrm{~Pb}$ & 669 & 660 & 6.5 & \\
\hline $07 \mathrm{~N}-17 \mathrm{E}-20 \mathrm{CCC} 2$ & Mendenha11, Ruth & 102 & $\mathrm{H}$ & 6 & $4 \mathrm{~A}$ & $5-76$ & $\mathrm{~Pb}$ & 664 & 660 & 7.7 & $Q$ \\
\hline $07 \mathrm{~N}-17 \mathrm{E}-20 \mathrm{DCC} 1$ & Mendenhal1, Ruth & 51 & $\mathrm{H}$ & 6 & $9 \mathrm{~A}$ & $5-76$ & $\mathrm{~Pb}$ & 662 & 900 & 7.1 & \\
\hline 07N-17E-26 DDD 1 & White, Earle & 97 & $\mathrm{H}$ & 6 & $21 \mathrm{~A}$ & 5-76 & $\mathrm{Pb}$ & 681 & 895 & 7.7 & \\
\hline $07 \mathrm{~N}-17 \mathrm{E}-27$ AAA 1 & Pruitt, O.A. & 73 & $\mathrm{H}$ & 6 & $\cdots$ & -- & $\mathrm{Pb}$ & 680 & 1,500 & 7.9 & \\
\hline 07N-17E-28 AAA 1 & Pruitt, O.A. & 20 & $\mathrm{U}$ & 24 & $8 \mathrm{~A}$ & $5-76$ & $\mathrm{~Pb}$ & 664 & 105 & 6.2 & \\
\hline $07 \mathrm{~N}-17 \mathrm{E}-30 \mathrm{AAB} 1$ & Wallace, Esther & 46 & $\mathrm{H}$ & 6 & $8 \mathrm{~A}$ & $5-76$ & $\mathrm{~Pb}$ & 663 & 280 & 5.7 & Q \\
\hline $07 \mathrm{~N}-17 \mathrm{E}-30$ ABB 1 & Gibson, Evertt & 85 . & $\mathrm{H}$ & 6 & $8 \mathrm{~A}$ & $5-76$ & $\mathrm{~Pb}$ & 659 & 550 & 6.8 & \\
\hline $07 \mathrm{~N}-17 \mathrm{E}-30 \mathrm{BAB} 1$ & Patrick, Wesley & 60 & $\mathrm{H}$ & 6 & $\cdots$ &.- & $\mathrm{Pb}$ & 645 & 900 & 7.3 & \\
\hline $07 \mathrm{~N}-17 \mathrm{E}-30$ BBA 1 & Bassett, Frank C. & 84 & $\mathrm{H}$ & 6 & $14 \mathrm{~A}$ & $5-76$ & $\mathrm{~Pb}$ & 645 & 290 & 7.1 & \\
\hline $07 \mathrm{~N}-17 \mathrm{E}-32$ DDA 1 & Cochran, Fred & 98 & $\mathrm{H}$ & 6 & $9 \mathrm{~A}$ & $5-76$ & $\mathrm{~Pb}$ & 960 & 340 & 6.6 & \\
\hline $07 \mathrm{~N}-17 \mathrm{E}-32 \mathrm{DDD} 1$ & Singhurst, Dean & 138 & $\mathrm{H}$ & 6 & $10 \mathrm{~A}$ & $5-76$ & $\mathrm{~Pb}$ & 948 & 440 & 6.9 & \\
\hline $07 \mathrm{~N}-17 \mathrm{E}-32 \mathrm{DDD} 2$ & Singhurst, Dean & 64 & $\mathrm{H}$ & 6 & $22 \mathrm{~A}$ & $5-76$ & $\mathrm{~Pb}$ & 941 & 890 & 6.8 & \\
\hline $07 \mathrm{~N}-17 \mathrm{E}-33$ DDD 1 & Forhand, E.L. & 70 & $\mathrm{H}$ & 8 & $17 \mathrm{~A}$ & $5-76$ & Ps & 650 & 1,620 & 7.7 & \\
\hline $07 \mathrm{~N}-17 \mathrm{E}-35$ AAC 1 & White, W. Earle & 99 & $\mathrm{H}$ & 6 & $16 \mathrm{~A}$ & $5-76$ & Ps & 679 & 1,020 & 8.3 & \\
\hline
\end{tabular}


Structurally, the area is dominated by the east-west trending Panther Mountain syncline and the adjacent Kinta anticline (pl. 1). Because of the geologic structure, the rock layers are tilted at the surface exposing bedding plane openings between layers of sandstone and partings between laminae of shale; these openings are the main avenues of water entry and movement. 0ther openings for water movement are fractures and joints that were developed during folding of the brittle rocks. Faults, if any are present, also may be water conduits but if the rocks are greatly crushed so that the openings are sealed, the faults may act as water barriers.

Alluvium along Jones, Blue, and Mathuldy Creek ( 1 1. 1) has a maximum thickness of about 10 to $15 \mathrm{ft}$ and consists of sandy and clayey silt and clay. When water is present in the alluvium, it is under water-table conditions. Similar water-table conditions may exist in the zone of weathered bedrock which extends to a depth of about $20 \mathrm{ft}$ in some parts of the area. Below the weathered zone the water is confined and occurs under artesian conditions. Because of the artesian pressure, water rises in deeper wells and generally is less than $30 \mathrm{ft}$ below the land surface in most of the area as shown by the data in table 1. The potentiometric contours ( 1 . 2), which are drawn in those parts of the area where adequate water-level data are available, also show that the water level rises to near the land surface.

Because of their composition and physical structure, rocks in the Blocker area have little porosity and permeability so that their ability to store and transmit water is limited. Bedding planes, shale partings, joints, and fractures in the rocks provide the only openings capable of storing and transmitting significant amounts of water.

Alluvium in the Blocker area is not a source of water to wells. Although the bedrock has limited permeability and storage capacity, wells ranging in depth from 11 to $213 \mathrm{ft}$ and averaging about $75 \mathrm{ft}$ yield enough water for household or stock supplies. No tests to determine actual well yields have been made. However, tests of wells penetrating similar rocks elsewhere in the coal field show that most wells yield less than $5 \mathrm{gal} / \mathrm{min}$. 
$\underline{\text { Recharge and Discharge }}$

Ground-water recharge is derived entirely from precipitation falling directly on or near the area. Although about 60 percent of the precipitation falls during spring and summer, ground-water levels as measured in various parts of the coal field show that little recharge takes place at that time because most of the water is lost by evapotranspiration before it can reach the saturated zone. Consequently, the ground-water level, which reflects the amount of water in storage, typically is lowest during late summer or early fall and is highest during late winter or early spring. Intermittent rains of an inch or so during summer, when evapotranspiration is greatest, may produce sharp but only temporary rises in the water level as shown by the hydrograph for well $07 \mathrm{~N}-16 \mathrm{E}-24 \mathrm{BAB} 1$ (fig. 2).

An estimate of the amount of recharge is based on the relationship that recharge equals discharge. Discharge from the aquifer includes evapotranspiration, discharge to streams, and pumpage. The following estimate was made for the winter months when evapotranspiration was negligible. Ground-water discharge to Blue Creek in November, 1976, and in November and December, 1977, averaged about 4.5 acre-ft. If the same discharge continued through the non-growing season, October through March, the total amount would be about 27 acre-ft per year. Ground-water pumpage is estimated a 9 acre-ft per year. Thus, the total amount of ground-water discharge, which is equivalent to recharge, is estimated at about 36 acre-ft per year or about 3 acre- $\mathrm{ft} / \mathrm{mi}^{2}$ per year.

An estimate of evapotranspiration is based on the difference between precipitation and runoff plus ground-water recharge. Groundwater recharge is insignificant compared to the total amount of precipitation. In 1977, precipitation was about 33 in. for a total of 21,300 acre-ft over the $12.1 \mathrm{mi}^{2}$ area. of this amount, runoff accounted for 3,670 acre-ft or 17 percent and the remainder, 83 percent, was consumed by evapotranspiration. In 1978, precipitation was about 30 in. for a total of 19,400 acre-ft and, of this, runoff accounted for 4,730 acre-ft, or about 24 percent, and evaporation accounted for 76 percent. These estimates, although crude, show that evapotranspiration in the Blocker area varies from year to year depending on climatic conditions. However, during most years about 80 percent of the precipitation probably is lost by evapotranspiration. 


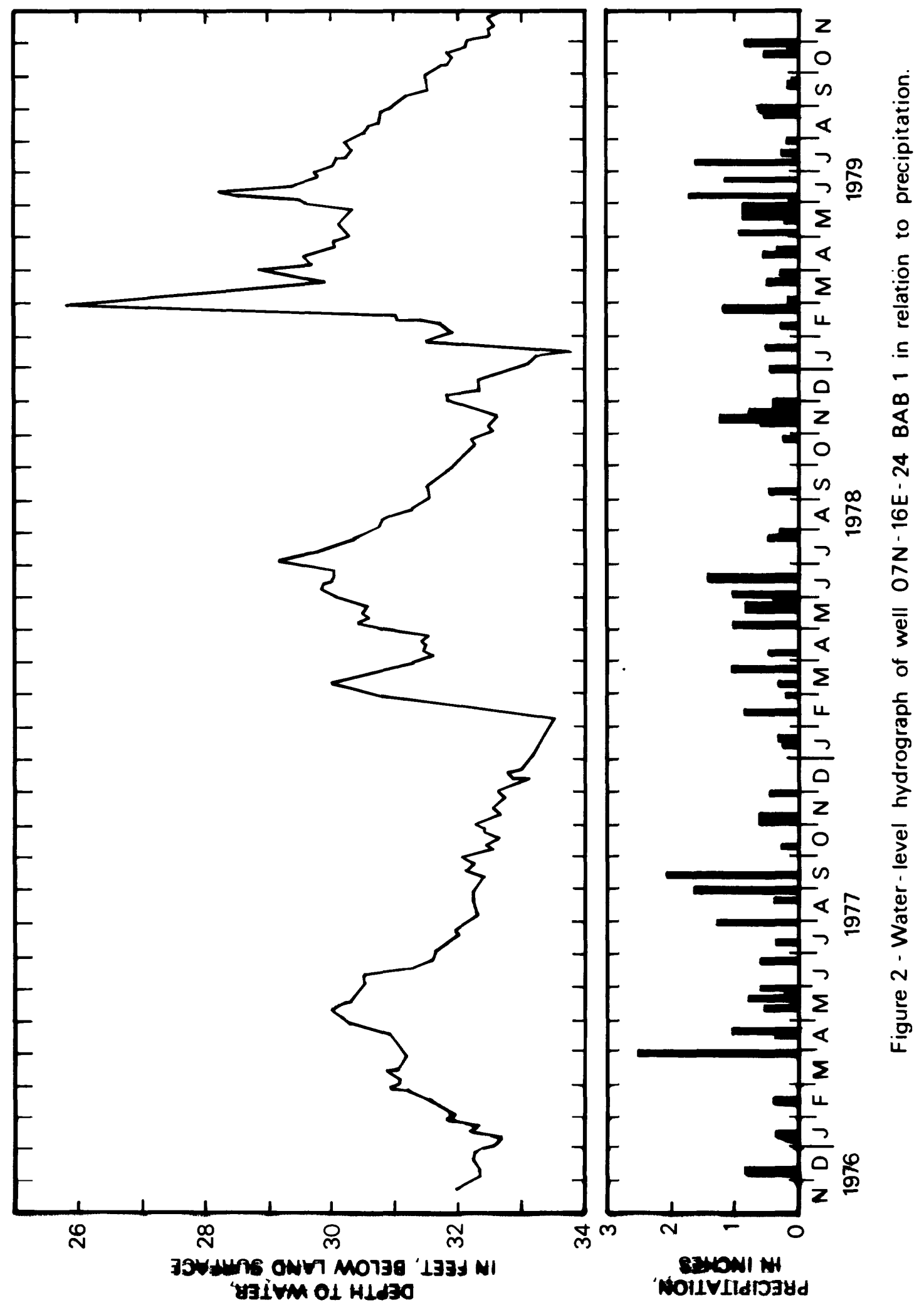


Stream Discharge Characteristics

Because the predominantly shale rocks lack the capacity to store water, streams draining the Blocker area are ephemeral and most of their flow is the result of storm runoff. The available discharge records for Blue Creek (table 2), Blue Creek tributary, (table 3), and Mathuldy Creek (table 4) show that these streams had no flow for extended periods during 1976-79. However, steamflow in the Blocker area during this interval may have been less than average because long-term streamflow records for a nearby gaging station on James Fork near Hackett, Arkansas, show that the average annual flow for 1976-79 was about 50 percent of the 20-year average.

The flow duration curve for Blue Creek (fig. 3) shows that for the period 1976-80 the stream had virtually no daily discharge (less than or equal to $\left.0.01 \mathrm{ft}^{3} / \mathrm{s}\right) 46$ percent of the time. Data in table 2 shows that periods of more than 60 consecutive days of virtually no flow occurred from mid-June to mid-September each year. In fact, flow was less than $0.1 \mathrm{ft}^{3} / \mathrm{s}$ for at least 90 consecutive days during these 3 months. Sustained flows for Blue Creek were recorded for NovemberMay except for a few isolated days. Sustained flows of $1 \mathrm{ft}^{3} / \mathrm{s}$ or more had a duration of less than 2 weeks and sustained flows of 10 $\mathrm{ft}^{3} / \mathrm{s}$ or more had a duration of less than 1 week. The mean annual daily flows ranged from about 5 to $8 \mathrm{ft}^{3} / \mathrm{s}$ for the 3 years.

Variations in runoff in response to rainfall in Blue Creek basin are due, in part, to: (1) differences in rainfall amounts, intensity, and duration; (2) effects of antecedent rainfall; (3) differences in distribution of rainfall over the basin; and (4) seasonal variations in evapotranspiration. In addition, before runoff occurs, soil moisture and depression storage requirements must be satisfied. A detailed discussion of these hydrologic relationships is beyond the scope of this report. However, hydrographs of runoff (fig. 4) in response to rainfalls of different duration, intensity, and distribution illustrate the variability of discharge of Blue Creek. Precipitation, as shown in figure 4, was measured at a gage about $1.25 \mathrm{mi}$ north of the stream-discharge gage.

In order to determine variations in rainfall in different parts of the basin of Blue Creek, two additional gages were installed at $07 \mathrm{~N}-17 \mathrm{E}-18 \mathrm{CCB} 1$ and $07 \mathrm{~N}-17 \mathrm{E}-32$ ACA 1 . At the same time, the gage at $07 \mathrm{~N}-16 \mathrm{E}-24$ DCC 1 was moved to $07 \mathrm{~N}-17 \mathrm{E}-25$ ACC 1 . Data provided by these gages (table 5) showed that precipitation differed significantly from one part of the basin to another. Table 5 also shows variations in runoff in response to seasonal variations in precipitation. 
Table 2.--Discharge of Blue Creek near Blocker, Okla., 1976-79 (Station 07232010).

LOCATION.--Lat $34^{\circ} 02^{\prime} 26^{\prime \prime}$, long $95^{\circ} 34^{\prime} 21^{\prime \prime}$, in SW/4, NW/4 sec. 36, T.7 N., R.16 E., Pittsburg County, Hydrologic Unit 11090204 on right bank at downstream side of bridge on State Highway 31 , 1.5 mile south of Blocker and at mile 3.9.

DRAINAGE AREA. --12.1 square miles.

PERIOD OF RECORD. - -January 1976 to September 1979.

GAGE.--Water-stage recorder. Datum of gage is 592.47 feet above National Geodetic Vertical Datum of 1929 (Oklahoma State Highway bench mark).

\begin{tabular}{|c|c|c|c|c|c|c|c|c|c|c|c|c|}
\hline \multicolumn{13}{|c|}{ Water Year October 1975 to September 1976} \\
\hline \multirow{2}{*}{\multicolumn{13}{|c|}{$\begin{array}{c}\text { Discharge, in cubic feet per second } \\
\text { Mean Values }\end{array}$}} \\
\hline & & & & & & & & & & & & \\
\hline DAY & OCT & $\mathrm{NOV}$ & DEC & JAN & FEB & MAR & APR & MAY & JUNE & JULY & AUG & SEPT \\
\hline 1 & & & & -- & 0.29 & 0.15 & 5.0 & 2.3 & 2.7 & 0.02 & 0.00 & 0.00 \\
\hline 2 & & & & --- & .34 & .13 & 3.3 & 1.2 & .75 & .02 & .00 & .00 \\
\hline 3 & & & & -- & .29 & .07 & 2.6 & .55 & .51 & .02 & .00 & .00 \\
\hline 4 & & & & --- & .25 & .02 & 2.0 & .34 & .33 & .02 & .00 & .00 \\
\hline 5 & & & & $\cdots$ & .25 & .02 & 1.5 & 37 & .15 & .02 & .00 & .00 \\
\hline 6 & & & & $\cdots$ & .21 & .02 & 1.3 & 49 & .15 & .02 & .00 & .00 \\
\hline 7 & & & & --- & .18 & .03 & 1.0 & 11 & .15 & .01 & .00 & .00 \\
\hline 8 & & & & --- & .18 & 187 & .87 & 5.5 & .10 & .01 & .00 & .00 \\
\hline 9 & & & & -- & .18 & 82 & .55 & 3.3 & .06 & .01 & .00 & .00 \\
\hline 10 & & & & --- & .15 & 16 & .40 & 1.5 & .02 & .01 & .00 & .00 \\
\hline 11 & & & & $\cdots$ & .18 & 27 & .34 & .87 & .01 & .01 & .00 & .00 \\
\hline 12 & & & & -.. & .21 & 51 & .29 & 233 & .01 & .00 & .00 & .00 \\
\hline 13 & & & & -- & .21 & 11 & .29 & 110 & .01 & .00 & .00 & .00 \\
\hline 14 & & & & $\cdots$ & .15 & 7.3 & .29 & 24 & .01 & .00 & .00 & .00 \\
\hline 15 & & & & -- & .15 & 5.0 & .21 & 45 & .01 & .00 & .00 & .00 \\
\hline 16 & & & & -- & .15 & 4.1 & .21 & 29 & .01 & .00 & .00 & .00 \\
\hline 17 & & & & -- & .13 & 2.9 & 1.2 & 11 & .01 & .00 & .00 & .00 \\
\hline 18 & & & & -- & .13 & 2.3 & 622 & 6.1 & .15 & .00 & .00 & .00 \\
\hline 19 & & & & --- & .13 & 2.0 & 507 & 3.3 & .05 & .00 & .00 & .00 \\
\hline 20 & & & & --- & .15 & 1.5 & 1,190 & 1.5 & .02 & .00 & .00 & .00 \\
\hline 21 & & & & -- & .34 & 1.2 & 38 & .87 & .02 & .00 & .00 & .00 \\
\hline 22 & & & & --- & .34 & .87 & 14 & .47 & .02 & .00 & .00 & .00 \\
\hline 23 & & & & -- & .25 & .65 & 8.5 & .29 & .01 & .00 & .00 & .00 \\
\hline 24 & & & & -- & .25 & .55 & 5.5 & .25 & 9.7 & .00 & .00 & .00 \\
\hline 25 & & & & -- & .18 & .65 & 3.3 & .25 & 2.6 & .00 & .00 & .00 \\
\hline 26 & & & &.-- & .25 & 1.2 & 1.7 & 70 & .21 & .00 & .00 & .00 \\
\hline 27 & & & & -. & .29 & 2.3 & 1.2 & 16 & .09 & .00 & .00 & .00 \\
\hline 28 & & & & -- & .25 & 2.0 & 5.5 & 7.3 & .04 & .00 & .00 & .00 \\
\hline 29 & & & & 0.18 & .15 & 78 & 7.3 & 3.9 & .03 & .00 & .00 & .00 \\
\hline 30 & & & ${ }^{\circ}$ & .25 &.- & 16 & 3.6 & 14 & .02 & .00 & .00 & .00 \\
\hline 31 & & & & .25 & --- & 8.5 & -- & 0.5 & -- & .00 & .00 & .00 \\
\hline TOTAL & & & & -- & 6.21 & 511.46 & $2,428.95$ & 695.29 & 17.95 & 0.17 & 0.00 & 0.00 \\
\hline MEAN & & & & -- & 0.21 & 16.5 & 81.0 & 22.4 & 0.60 & 0.006 & 0.00 & 0.00 \\
\hline MAXIMUM & & & & -- & 0.34 & 187 & 1,190 & 233 & 9.7 & 0.02 & 0.00 & 0.00 \\
\hline MINIMUM & & & & --- & 0.13 & 0.02 . & 0.21 & 0.25 & 0.01 & 0.00 & 0.00 & 0.00 \\
\hline ACRE-FEET & & & & -. & 12 & 1,010 & 4,820 & L, 380 & 36 & 0.3 & 0.00 & 0.00 \\
\hline
\end{tabular}


Table 2.--Discharge of Blue Creek near Blocker, Okla., 1976-79 (Station 07232010)--Continued

\begin{tabular}{|c|c|c|c|c|c|c|c|c|c|c|c|c|}
\hline \multicolumn{13}{|c|}{ Water Year October 1976 to September 1977} \\
\hline \multicolumn{13}{|c|}{$\begin{array}{c}\text { Discharge, in cubic feet per second } \\
\text { Mean Values }\end{array}$} \\
\hline DAY & OCT & NOV & DEC & JAN & FEB & MAR & APR & MAY & JUNE & JULY & AUG & SEPT \\
\hline 1 & 0.00 & 0.12 & 0.04 & 0.03 & 0.02 & 0.37 & 4.7 & 0.28 & 0.09 & 0.00 & 0.00 & 0.00 \\
\hline 2 & .00 & .10 & .04 & .03 & .02 & .37 & 3.7 & .23 & .08 & .00 & .00 & .00 \\
\hline 3 & .00 & .09 & .04 & .03 & .50 & 2.5 & 2.5 & .20 & .06 & .00 & .00 & .00 \\
\hline 4 & .00 & .11 & .04 & .03 & .05 & 3.2 & 2.2 & .18 & .06 & .00 & .00 & .00 \\
\hline 5 & .00 & .12 & .04 & .03 & .03 & 1.6 & .89 & .16 & .05 & .00 & .00 & .00 \\
\hline 6 & .00 & .12 & 6.2 & .03 & .02 & .86 & .62 & .13 & .05 & .00 & .00 & .00 \\
\hline 7 & .00 & .11 & 1.1 & .03 & .02 & .68 & .55 & .11 & .05 & .00 & .00 & .00 \\
\hline 8 & .00 & .11 & .41 & .03 & .02 & .55 & .38 & .33 & .04 & .00 & .00 & .00 \\
\hline 9 & .00 & .11 & .23 & .03 & .29 & .45 & .36 & 1.4 & .04 & .00 & .00 & .00 \\
\hline 10 & .00 & .11 & .16 & .04 & 1.0 & .41 & .28 & .21 & .03 & .00 & .00 & .00 \\
\hline 11 & .00 & .11 & .55 & .04 & 13 & 1.2 & .26 & .14 & .02 & .00 & .00 & .00 \\
\hline 12 & .00 & .11 & .45 & .16 & 15 & 2.8 & .24 & .10 & .01 & .00 & .00 & .00 \\
\hline 13 & .00 & .11 & .33 & .41 & 5.2 & 2.1 & .21 & .09 & .00 & .00 & .00 & 82 \\
\hline 14 & .00 & .11 & .23 & 7.8 & 3.0 & 1.4 & .18 & .08 & .00 & .00 & .00 & 7.4 \\
\hline 15 & .00 & .11 & .18 & 6.6 & 1.4 & .77 & .21 & .07 & .00 & .00 & .00 & 1.4 \\
\hline 16 & .00 & .09 & .13 & 4.0 & .86 & .50 & .26 & .07 & .00 & .00 & .00 & .35 \\
\hline 17 & $: 00$ & .09 & .10 & 1.1 & .68 & .45 & .41 & .07 & .00 & .00 & .00 & .19 \\
\hline 18 & .00 & .08 & .09 & 1.1 & .50 & .41 & 11 & .06 & .00 & .00 & .00 & .14 \\
\hline 19 & .00 & .03 & .09 & .50 & .41 & .33 & 21 & .05 & .00 & .00 & .00 & .11 \\
\hline 20 & .00 & .03 & .08 & .20 & .33 & .26 & 19 & .96 & .00 & .00 & .00 & .10 \\
\hline 21 & .00 & .03 & .07 & .10 & .30 & .23 & 21 & .68 & .00 & .00 & .00 & .09 \\
\hline 22 & .00 & .03 & .06 & .05 & .28 & .20 & 12 & .28 & .00 & .00 & .00 & .09 \\
\hline 23 & .00 & .04 & .06 & .30 & .41 & .18 & 6.2 & .14 & .00 & .00 & .00 & .08 \\
\hline 24 & 1.4 & .04 & .06 & 6.0 & 1.1 & .18 & 3.7 & .10 & .00 & .00 & .00 & .07 \\
\hline 25 & 1.8 & .04 & .06 & 2.0 & .80 & .18 & 1.6 & .08 & .00 & .00 & .00 & .07 \\
\hline 26 & .12 & .04 & .06 & 1.0 & .60 & 10 & .86 & .07 & .00 & .00 & .00 & .06 \\
\hline 27 & .05 & .04 & .06 & .50 & .55 & 1,300 & .55 & .06 & .00 & .00 & .00 & .06 \\
\hline 28 & .05 & .04 & .05 & .20 & .45 & 146 & .41 & 20 & .00 & .00 & .00 & .06 \\
\hline 29 & .05 & .04 & .05 & .10 & $-\cdots$ & 29 & .33 & 3.7 & .00 & .00 & .00 & .06 \\
\hline 30 & .14 & .04 & .04 & .05 & $\cdots$ & 13 & .30 & .30 & .00 & .00 & .03 & .05 \\
\hline 31 & .24 & -.- & .03 & .30 & --- & 6.7 & --- & .14 & --- & .00 & .03 & $-\ldots$ \\
\hline TOTAL & 3.85 & 2.35 & 11.13 & 32.82 & 46.90 & $1,526.88$ & 115.90 & 30.47 & 0.58 & 0.00 & 0.06 & 92.38 \\
\hline MEAN & 0.12 & 0.078 & 0.36 & 1.06 & 1.68 & 49.3 & 3.86 & 0.98 & 0.019 & 0.000 & 0.002 & 3.08 \\
\hline MAXIMUM & 1.8 & 0.12 & 6.2 & 7.8 & 15 & 1,300 & 21 & 20 & 0.09 & 0.00 & 0.03 & 82 \\
\hline MINIMUA & 0.00 & 0.03 & 0.03 & 0.03 & 0.02 & 0.18 & 0.18 & 0.05 & 0.00 & 0.00 & 0.00 & 0.00 \\
\hline ACRE-FEET & 7.6 & 4.7 & 22 & 65 & 93 & 3,030 & 230 & 60 & 1.2 & 0.00 & 0.1 & 183 \\
\hline
\end{tabular}

WATER YEAR 1977 TOTAL $1,863.32$ MEAN 5.10 MAXIMU 1,300 MINIMUM $0.00 \quad$ ACRE-FEET 3,700 
Table 2.--Discharge of Blue Creek near Blocker, Okla., 1976-79 (Station 07232010)--Continued

\begin{tabular}{|c|c|c|c|c|c|c|c|c|c|c|c|c|}
\hline \multicolumn{13}{|c|}{ Water Year October 1977 to September 1978} \\
\hline \multirow{2}{*}{\multicolumn{13}{|c|}{$\begin{array}{c}\text { Discharge, in cubic feet per second } \\
\text { Mean Values }\end{array}$}} \\
\hline & & & & & & & & & & & & \\
\hline DAY & ФT & NOV & $\mathrm{DEC}$ & JAN & FEB & MAR & APR & MAY & JUNE & JULY & AUG & SEPT \\
\hline 1 & 0.03 & 0.07 & 0.08 & 0.03 & $0.38^{\circ}$ & 9.4 & 1.4 & 0.38 & 13 & 0.08 & 0.00 & 0.00 \\
\hline 2 & .02 & .06 & .06 & .03 & .38 & 5.6 & 1.1 & .25 & 35 & .06 & .00 & .00 \\
\hline 3 & .02 & .05 & .09 & .03 & .38 & 3.8 & .98 & 17 & 180 & .05 & .00 & .00 \\
\hline 4 & .02 & .05 & .12 & .03 & .38 & 2.0 & 1.8 & 5.2 & 22 & .04 & .00 & .00 \\
\hline 5 & .00 & .05 & .12 & .02 & .69 & 1.6 & 1.8 & 6.7 & 16 & .04 & .00 & .00 \\
\hline 6 & .00 & .05 & .10 & .00 & .74 & 1.5 & 2.4 & 7.3 & 31 & .03 & .00 & .00 \\
\hline 7 & .00 & .05 & .12 & .00 & .54 & 38 & 2.2 & 5.6 & 16 & .02 & .00 & .00 \\
\hline 8 & .05 & .14 & .10 & .00 & .38 & 15 & 1.6 & 3.8 & 13 & .02 & .00 & .00 \\
\hline 9 & .03 & .09 & .08 & .00 & .50 & 6.7 & 1.3 & 1.8 & 5.6 & .01 & .00 & .00 \\
\hline 10 & .02 & .07 & .08 & .02 & .31 & 3.4 & 22 & 1.1 & 2.2 & .01 & .00 & .00 \\
\hline 11 & .01 & .08 & .08 & .02 & .31 & 2.4 & 16 & .79 & 1.1 & .00 & .00 & .00 \\
\hline 12 & .00 & .10 & .07 & .01 & 49 & 1.8 & 7.3 & .64 & .79 & .00 & .00 & .00 \\
\hline 13 & .00 & .09 & .07 & .01 & 63 & 1.5 & 4.2 & .46 & .54 & .00 & .00 & .00 \\
\hline 14 & .00 & .09 & .07 & .01 & 8.0 & 1.4 & 2.4 & .38 & .42 & .00 & .00 & .00 \\
\hline 15 & .00 & .10 & .07 & .01 & 3.8 & 1.1 & 2.0 & .31 & .31 & .00 & .00 & .00 \\
\hline 16 & .00 & .09 & .07 & .08 & 2.7 & .98 & 1.4 & .28 & .22 & .00 & .00 & .00 \\
\hline 17 & .00 & .09 & .08 & .07 & 2.4 & .85 & 1.1 & .25 & .17 & .00 & .00 & .00 \\
\hline 18 & .00 & .08 & .06 & .07 & 1.5 & .74 & .91 & .25 & 24 & .00 & .00 & .00 \\
\hline 19 & .00 & .07 & .06 & .06 & 1.5 & .64 & .64 & .25 & 4.2 & .00 & .00 & .00 \\
\hline 20 & .00 & .07 & .04 & .05 & 1.6 & .59 & .54 & 18 & .98 & .00 & .00 & .00 \\
\hline 21 & .00 & .09 & .03 & .06 & 1.4 & .59 & .50 & 6.7 & 41 & .00 & .00 & .00 \\
\hline 22 & .00 & .09 & .03 & .08 & 4.2 & .54 & .42 & 749 & 21 & .00 & .00 & .00 \\
\hline 23 & .00 & .09 & .03 & .09 & 23 & 158 & .38 & 26 & 4.2 & .00 & .00 & .00 \\
\hline 24 & .00 & .08 & .03 & .17 & 15 & 244 & .34 & 8.7 & 1.4 & .00 & .00 & .00 \\
\hline 25 & .00 & .06 & .04 & .64 & 7.3 & 23 & .31 & 3.4 & .79 & .00 & .00 & .00 \\
\hline 26 & .00 & .05 & .06 & .91 & 3.4 & 12 & .28 & 2.0 & .31 & .00 & .00 & .00 \\
\hline 27 & .00 & .05 & .07 & .69 & 4.7 & 6.2 & .22 & 1.1 & .29 & .00 & .00 & .00 \\
\hline 28 & .00 & .07 & .06 & .50 & 25 & 4.2 & .19 & 3.4 & .21 & .00 & .00 & .00 \\
\hline 29 & .00 & .09 & .06 & .42 & $\cdots$ & 3.0 & .22 & 2.7 & .12 & .00 & .00 & $\cdot .00$ \\
\hline 30 & .00 & .17 & .04 & .42 & -..- & 2.2 & .25 & 1.1 & .10 & .00 & .00 & .00 \\
\hline 31 & .00 & $\cdots$ & .04 & .38 & $\cdots$ & 1.6 & $\cdots$ & .85 & $\cdots$ & .00 & .00 & $\cdots$ \\
\hline TOTAL & 0.20 & 2.38 & 2.11 & 4.91 & 222.49 & 554.33 & 76.18 & 875.69 & 559.95 & 0.36 & 0.00 & 0.00 \\
\hline MEAN & 0.006 & 0.079 & 0.068 & 0.16 & 7.95 & 17.9 & 2.54 & 28.2 & 18.7 & 0.012 & 0.000 & 0.000 \\
\hline MAXIMUM & 0.05 & 0.17 & 0.12 & 0.91 & 63 & 244 & 22 & 749 & 180 & 0.08 & 0.00 & 0.00 \\
\hline MINIMUM & 0.00 & 0.05 & 0.03 & 0.00 & 0.31 & 0.54 & 0.19 & 0.25 & 0.10 & 0.00 & 0.00 & 0.00 \\
\hline ACRE-FEET & 0.4 & 4.7 & 4.2 & 9.7 & 441 & 100 & 151 & 1,740 & 1,110 & 0.70 & 0.00 & 0.00 \\
\hline
\end{tabular}



CALENDAR YEAR 1977 TOTAL $1,850.68$ MEAN 5.07 MAXIMUM $1,300 \quad$ MINIMUM $0.00 \quad$ ACRE-FEET 3,670

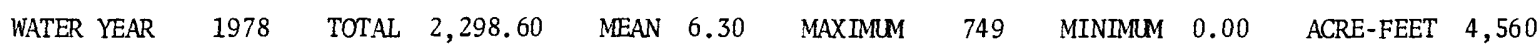


Table 2.--Discharge of Blue Creek near Blocker, Okla., 1976-79 (Station 07232010)--Continued

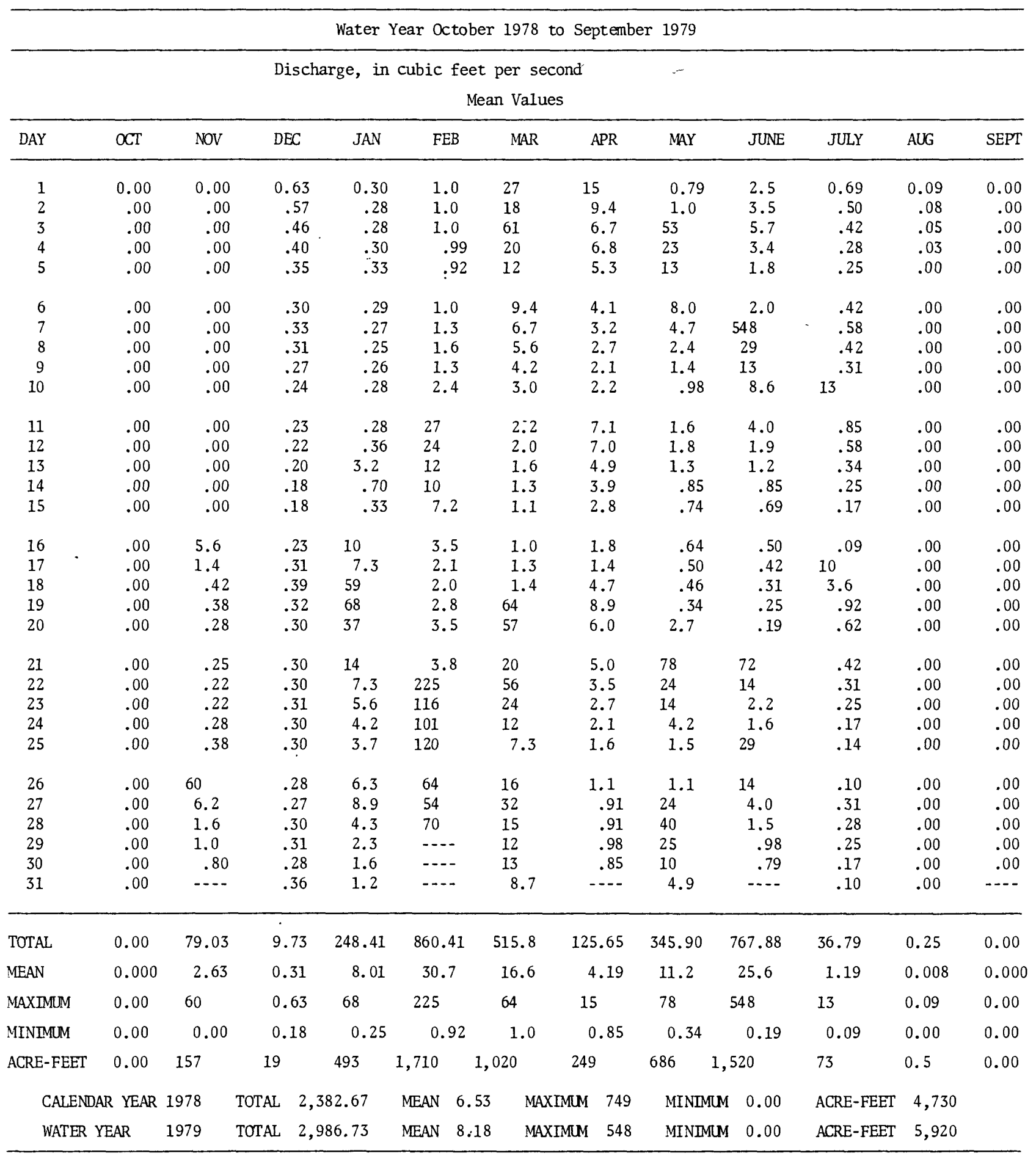


Table 3.--Discharqe of Blue Creek tributary near Blocker, Okla., 1978-79 (Station 07232008)

LOCATION.--Lat $35^{\circ} 02^{\prime} 25^{\prime \prime}$, lonq $95^{\circ} 34^{\prime} 15^{\prime \prime}$, NE 1/4, NW 1/4, sec. 36 , T. 7 N., R. 16 E., Pittsburq County, Hydroloqic Unit 1109204, approximately 400 feet east of State Hiahway 31 bridqe along Rlue Creek, 1.5 miles south of Rlocker and at mile 0.0 .

DRAINAGE AREA.--7.36 square miles.

PERIOD OF RECORD.--October 1978 to September 1979.

Water Year October 1978 to September 1979

\begin{tabular}{lcc} 
& & \multicolumn{2}{c}{ Nischarge } \\
Date & Time & (in cubic feet per second) \\
\hline Nov. 30 & 0930 & 0.89 \\
Dec. 11 & 1445 & .09 \\
Dec. 18 & 1540 & .14 \\
Jan. 30 & 1120 & .97 \\
Feb. 8 & 1215 & .64 \\
Feb. 27 & 1420 & 25 \\
Mar. 8 & 1430 & 2.1 \\
Mar. 23 & 1230 & 12 \\
Apr. 10 & 0900 & .82 \\
Apr. 19 & 1300 & 3.3 \\
May 3 & 1400 & 24 \\
May 25 & 1130 & 2.0 \\
June 4 & 1515 & 1.8 \\
June 26 & 1545 & 6.5 \\
July 11 & 1455 & .06 \\
\end{tabular}


Table 4.--Discharqe of Mathuldy Creek near Crowder, Okla., 1976-79 (Station 07232029)

LOCATION.--Lat $35^{\circ} 04^{\prime} 17^{\prime \prime}$, long $95^{\circ} 36^{\prime} 47^{\prime \prime}$, NE 1/4, NE 1/4, sec. 21

T. 7 N., R. 16 F., Pittsburq County, Hydrologic Init 11090204 , on county road bridge 4.3 miles southeast of Crowder and at mile 6.7.

DRAINAGE AREA.--5.41 square miles.

PERIOD OF RECORD.--January 1976 to Septemher 1979.

Water Year October 1975 to September 1976

\begin{tabular}{lcc} 
& & \multicolumn{2}{c}{ Discharge } \\
Date & Time & (in cubic feet per second) \\
\hline Mar. 17 & 1445 & 1.2 \\
Apr. 21 & 1154 & 16 \\
May 18 & 0930 & 4.2 \\
June 16 & 1227 & 0.00 \\
July 20 & 1510 & .00 \\
Aug. 10 & -- & .00 \\
Sept. 23 & -- & .00 \\
Oct. 19 & -- & .00 \\
Dec. 14 & 1230 & 1.0 \\
Jan. 18 & -- & .00 \\
Mar. 15 & 1130 & 1.5 \\
Apr. 17 & 1610 & 22 \\
May 17 & -- & .00 \\
June 14 & -- & .00 \\
July 19 & -- & .00 \\
Aug. 15 & -- & .00 \\
Sept. 20 & -- & .00
\end{tabular}

Water Year October 1976 to September 1977

Oct. 19

Dec. 14

Jan. 18

Mar. 15

Apr. 17

May 17

June 14

July 19

Aug. 15

Sept. 20
1230

--

1130

1610

--



-.

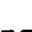

.00

1.0

.00

1.5

22

.00

.00

.00

. $\mathrm{nO}$ 
Table 4.--Discharge of Mathuldy Creek near Crowder, Okla., 1976-79 (Station 07232029).--Continued.

Water Year October 1977 to September 1978

Discharge

\begin{tabular}{lcc} 
Date & Time & (in cubic feet per second) \\
\hline Dec. 5 & 1120 & .40 \\
Jan. 26 & 1400 & 2.2 \\
Feb. 7 & 1500 & .90 \\
Mar. 7 & 1330 & 62 \\
Apr. 5 & 0810 & 1.1 \\
May 3 & 0815 & 18 \\
June 21 & 1145 & .23
\end{tabular}

Water Year October 1978 to September 1979

$\begin{array}{lcc}\text { Nov. } 30 & 1230 & 0.18 \\ \text { Jan. } 29 & 1450 & .74 \\ \text { Feb. 14 } & 1115 & 3.6 \\ \text { Feb. 23 } & 1015 & 20 \\ \text { Mar. 9 } & 1030 & 1.3 \\ \text { Mar. 22 } & 1630 & 32 \\ \text { Apr. 6 } & 0855 & 1.1 \\ \text { Apr. 20 } & 1000 & 1.1 \\ \text { May 3 } & 1545 & 17 \\ \text { May 24 } & 1015 & .3 \\ \text { June 4 } & 1345 & .12 \\ \text { June 21 } & 1655 & 14 \\ \text { June 21 } & 2035 & .06 \\ \text { July 13 } & 0830 & \end{array}$




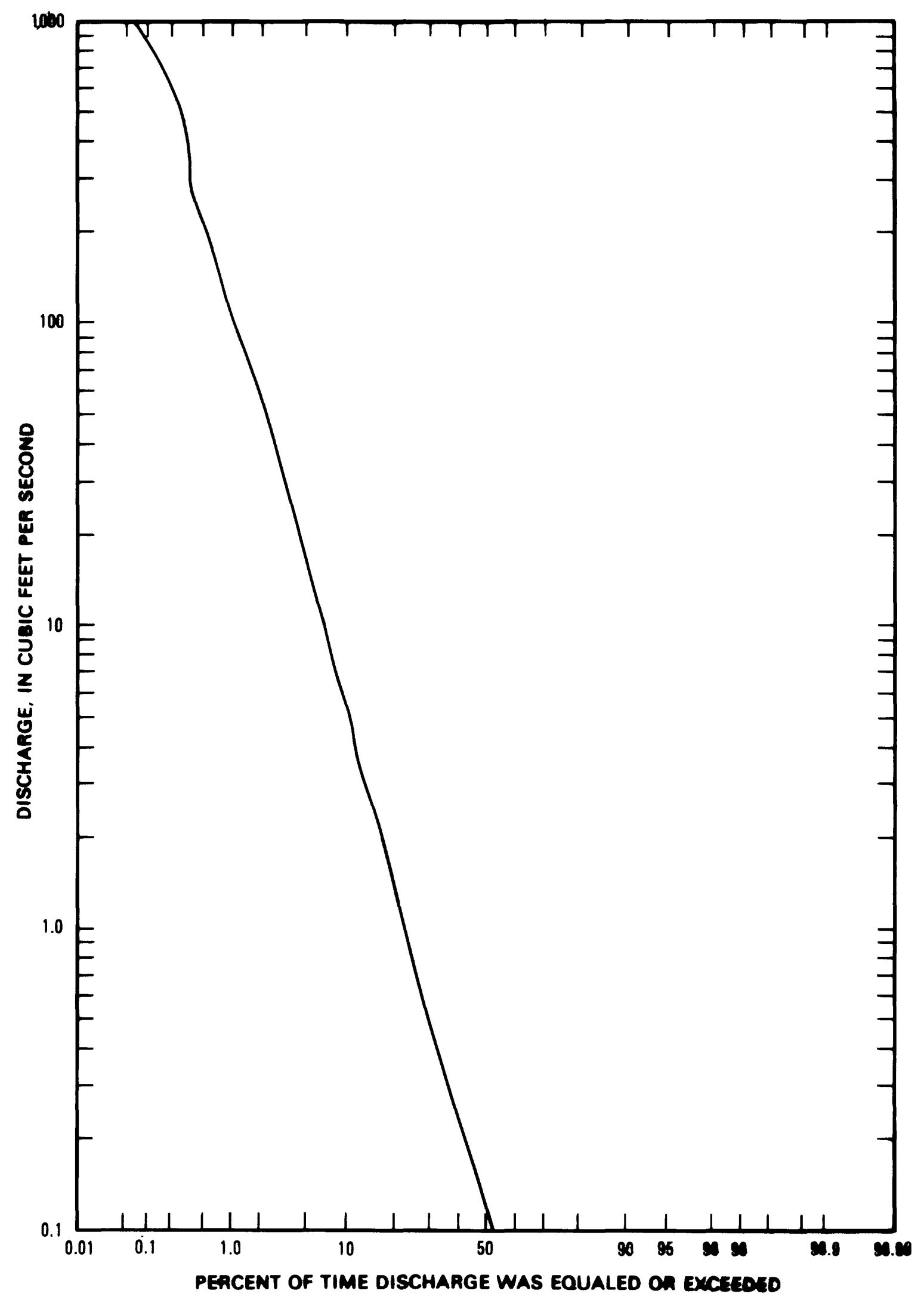

Figure 3. Flow duration curve of Blue Creok, 1976-80. 


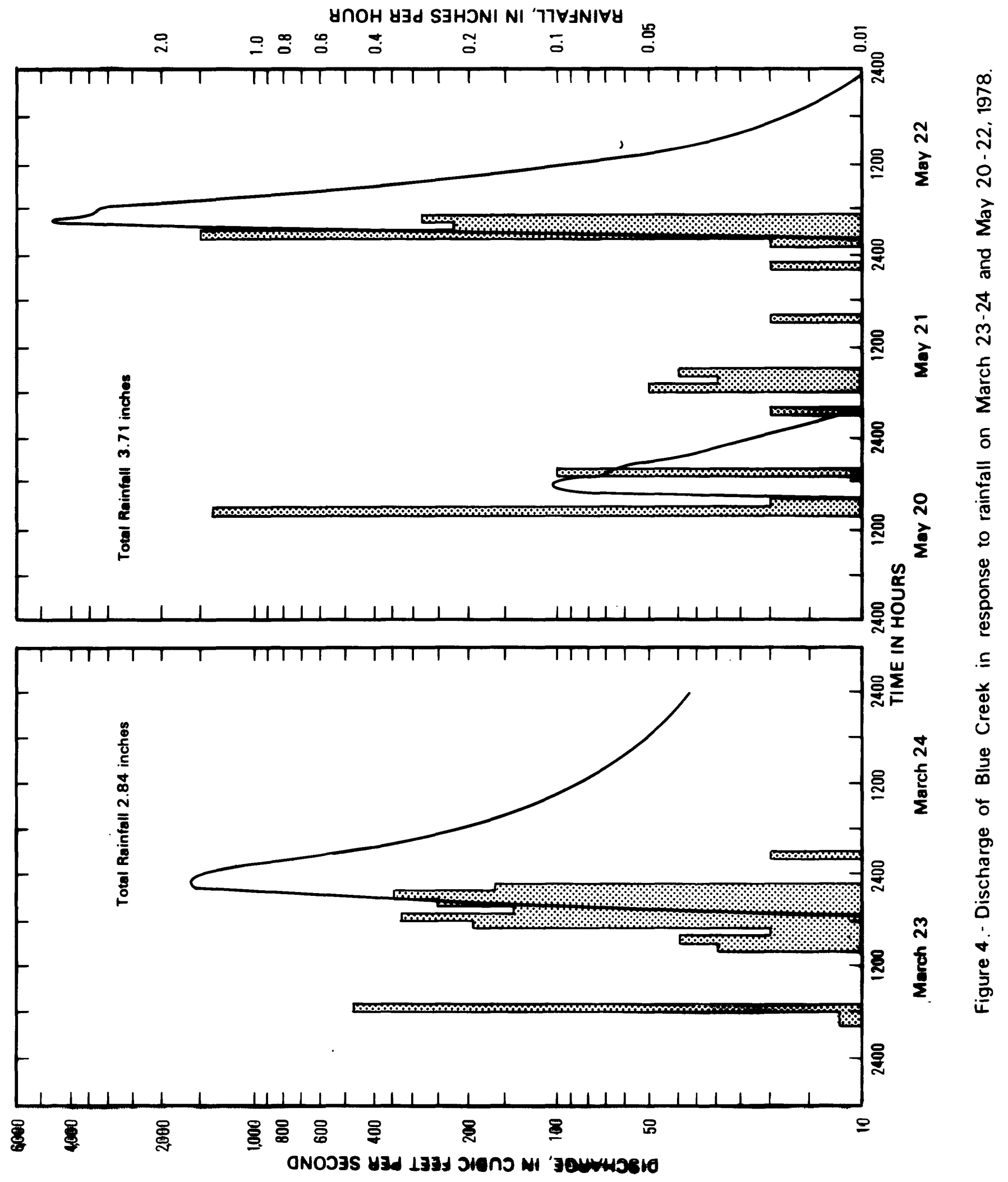




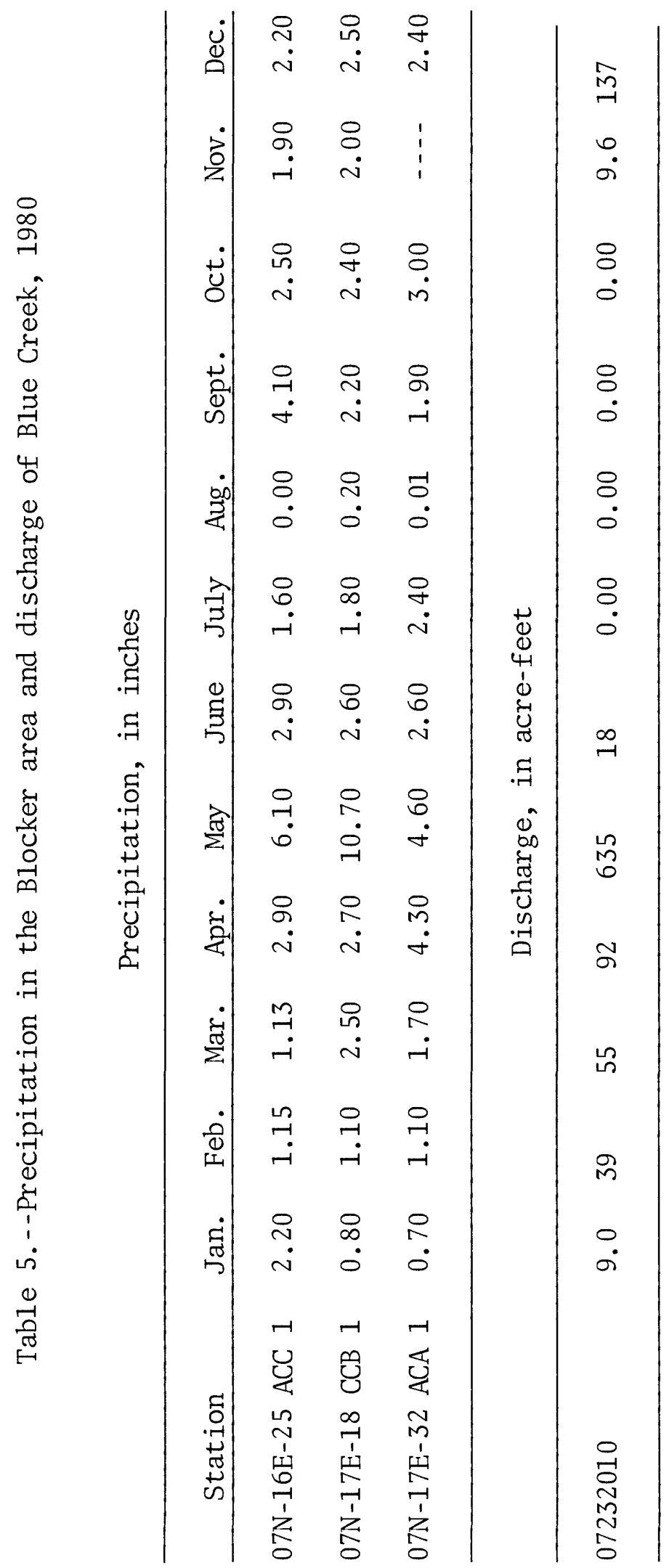




\section{Flood Frequencies}

As described by Sauer $(1974$, p. 10), the relation of flood-peak magnitude to probability of occurrence, or recurrence interval, is generally referred to as a flood-frequency relation. Probability of occurrence is the percent chance of a given flood magnitude being exceeded in any one year. Recurrence interval is the reciprocal of probability of occurrence times 100, and is the average number of years between exceedances. It is emphasized that recurrence interval is an average interval. For instance, a flood having a probability of occurrence of 2 percent has a recurrence interval of 50 years. This does not mean that each 50 years this flood will be exceeded, but that it will be exceeded on the average of every 50 years.

Computed flood frequencies for Blue Creek, which were estimated using previously derived regression equations (Thomas and Corley, 1977), are given below. The regression equations relate basin characteristics to the expected frequency of the computed flood discharge. Basin characteristics are: drainage area, $12.1 \mathrm{mi}^{2}$; channel slope, $24.1 \mathrm{ft} / \mathrm{mi}$; and annual precipitation, 42 in. The maximum recorded instantaneous discharge for $1976-79$ was $6,170 \mathrm{ft}^{3} / \mathrm{s}$, April $19,1976$.

Estimated
recurrence interval
(years)

Instantaneous

discharge

(cubic feet

per second)

\begin{tabular}{rc} 
& per second \\
2 & 1,640 \\
5 & 2,840 \\
10 & 3,900 \\
25 & 5,290 \\
50 & 6,300 \\
100 & 7,600 \\
\hline
\end{tabular}




\section{Flood-Prone Areas}

Large storms generate high streamflows that inundate flood-plains adjacent to stream channels. Approximate boundaries of flood-prone areas can be delineated on topographic maps when water surface profiles are known or can be computed, or when regional equations are available for computation of flood depths for various recurrence intervals.

Regional equations (Thomas, 1976) were used to compute the 100-year flood depths for Blue, Mathuldy, and Jones Creeks (pl. 3). Approximate boundaries were drawn on the topographic map as indicated by the computed flood depths. The approximate 100-year flood-prone area shows where there is a 1-in-100 chance of flooding during any year.

\section{WATER QUALITY}

All natural waters contain mineral constituents dissolved from the rock and soil with which the water has been in contact. Concentrations of the dissolved constituents largely depends on the type of soil or rock, the length of contact time, and pressure and temperature conditions. In addition to these natural conditions, man's activities, such as disposal of sewage and industrial wastes, diversion and use of water, agricultural practices, and activities associated with mineral or fuel production, can have a significant effect on the chemical quality of the water.

The Blocker area is rural with no industrial development and no municipal waste-disposal systems. The unwooded lands are used for cattle grazing and, other than home gardens and limited cutting of hay, there are no agricultural activities in the area. Timber in the area is not used for lumber. A few natural gas wells have been drilled but, as far as is known, none of them produce saltwater. In sum, there are no man-induced activities in the area that would significantly affect the chemical quality of water. 


\section{Surface Water}

\section{Water Type}

Water can be typed or classified according to the percentage of each of the major ions in solution. For example, if the calcium and sulfate ions each constitutes at least 50 percent of its respective cation or anion group, the water can be described as calcium sulfate type. The major cations - calcium, magnesium, and sodium plus potassium - and the major anions - carbonate-bicarbonate, chloride, and sulfate - generally constitute more than 95 percent of the total ions in solution. The potassium ion ordinarily is grouped with the sodium ion because its concentration is very small in relation to the sodium ion and because it is chemically similar to sodium. The relationship between carbonate and bicarbonate ions is $\mathrm{pH}$ dependent. When the $\mathrm{pH}$ is greater than 8.3, both carbonate and bicarbonate ions are considered to be present; when the $\mathrm{pH}$ is equal to or less than 8.3, only the bicarbonate ion is considered to be present.

A trilinear diagram can be used to show the ratio (percentage reacting values) of each major cation or anion, expressed in milliequivalents per liter, to the respective sum of the cations or anions, in milliequivalents per liter. This method of graphically displaying the major ion chemistry is fully described by Piper (1944) and Hem (1970). The percentage reacting values for the period of record were plotted (fig. 5) and show that no specific water type predominates.

In about one-half the samples analyzed, sulfate accounted for more than 50 percent of the anions, indicating a tendency towards mixed cation sulfate type water. Graphs of the anion ratios versus specific conductance for the three sites (fig. 6) were prepared to determine whether the predominance of sulfate is related to increasing specific conductance, which is proportional to the dissolved-solids concentration. The graphs show that the ion ratio for sulfate is not related to specific conductance, and therefore in general, the waters at the three sites are of a mixed type throughout the range of measured specific conductance.

The ratio of the milliequivalents of sodium to the milliequivalents of calcium plus magnesium (A ratio) and the ratio of the milliequivalents of bicarbonate plus chloride to the milliequivalents of sulfate (B ratio) for water from each of the three streams were compared to determine whether the water composition was the same. The Duncan's multiple range test at the 95-percent probability level showed the $B$ ratios to be the same for all three streams. The analysis of variance also showed the A ratio for Blue Creek and Blue Creek tributary to be the same yet both to be different from the A ratio for Mathuldy Creek. These tests indicated that water in Mathuldy Creek tends more toward a calcium magnesium sulfate water than does the water in Blue Creek and Blue Creek tributary. 


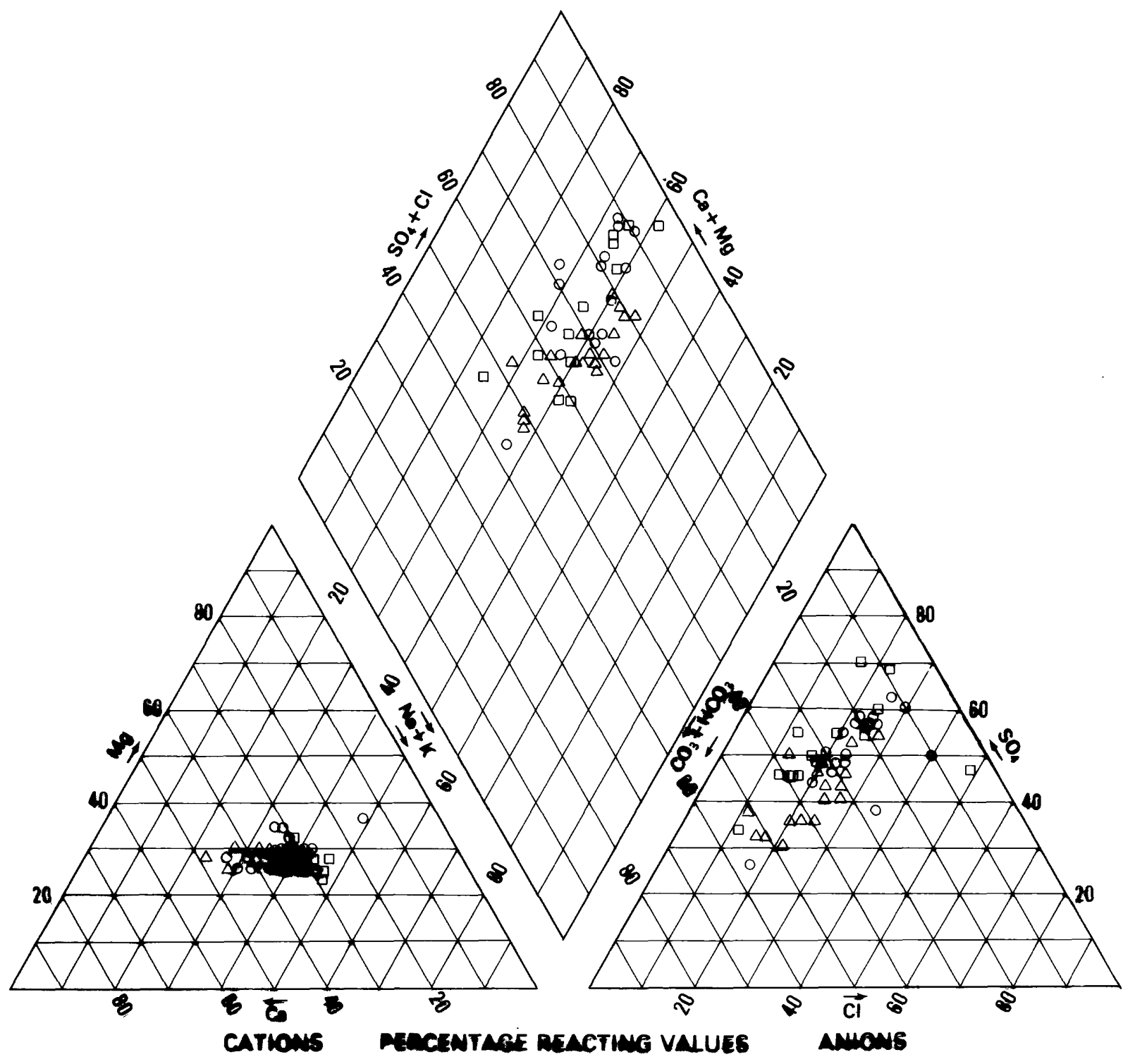

Figure 5.- Trilinaar diagram for water from stresms. Triangles represent water from Blue Creok, circles represent water from Blue Creak tributary, and squares represent water from Mathuldy Creak. 


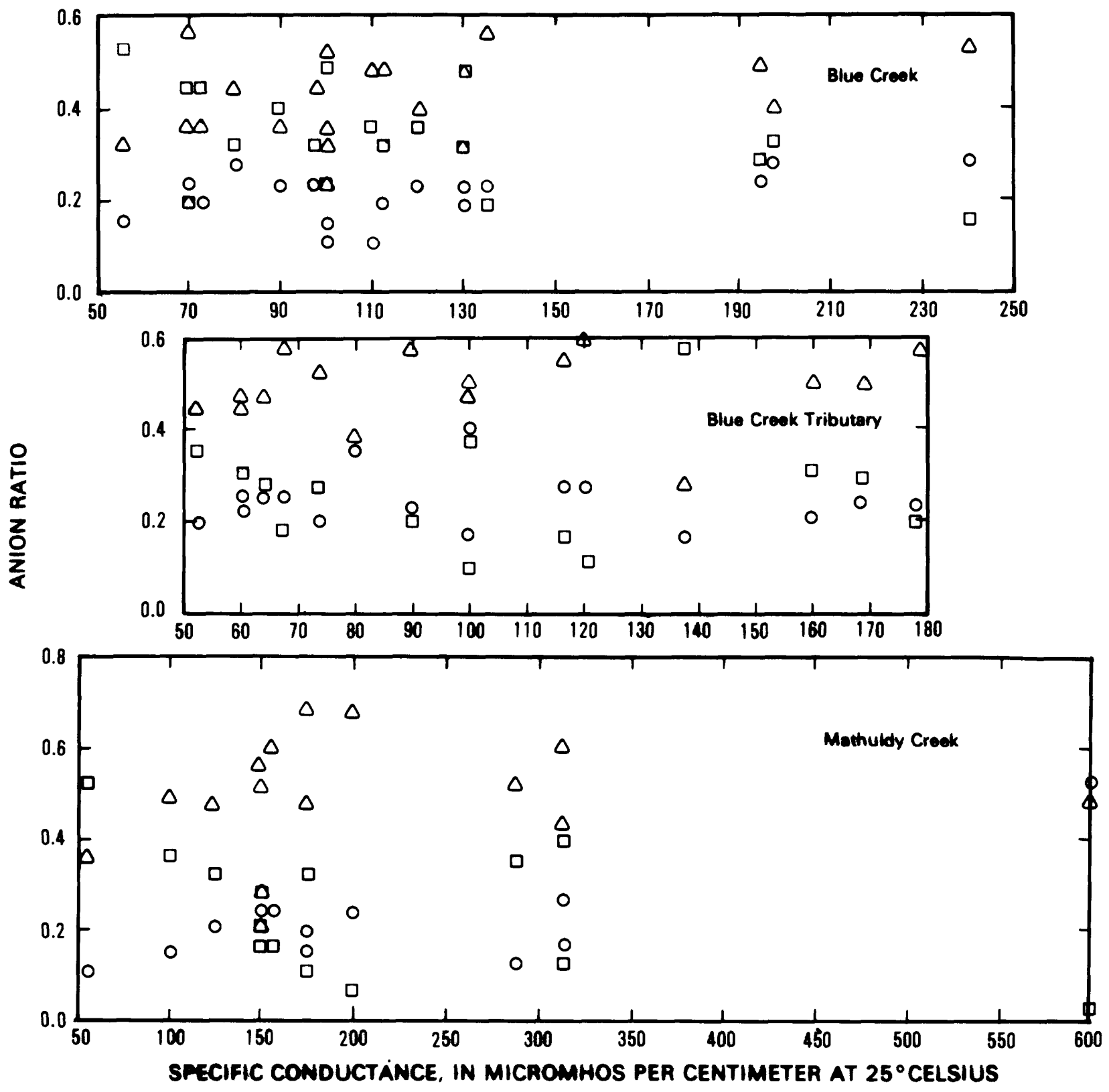

Figure 6. - Specific conductance versus anion ratios of stream waters. Square is bicarbonate, circle is chloride, triangle is sulfate. 


\section{Constituent Concentrations}

A summary of selected physical properties and chemical constituents of water from each of the three streams is given in tables 6-8. As shown by these data, the maximum dissolved-solids concentration of $359 \mathrm{mg} / \mathrm{L}$ (milligrams per liter) is for Mathuldy Creek water. The Duncan's multiple range test at the 95-percent probability level shows that the mean concentrations of the major constituents - bicarbonate, sodium, and chloride - are the same for all three streams. of the mean concentrations that were different - calcium, magnesium, potassium, and sulfate - the analysis of variance shows that water from Mathuldy Creek has larger mean concentrations. The Duncan's multiple range test at the 95-percent probability level for dissolved solids shows that mean dissolved solids concentrations are different, and that the water in Mathuldy Creek is more concentrated.

Maximum contaminant levels in public water supplies have been established for the toxic elements - arsenic, cadmium, chromium, lead, and mercury - by the U.S. Environmental Protection Agency (1976). of these elements, dissolved lead in water from Blue Creek tributary exceeded the maximum level of $50 \mathrm{ug} / \mathrm{L}$ (micrograms per liter) in one sample and total mercury in water from Blue Creek exceeded the maximum level of $2.0 \mathrm{ug} / \mathrm{L}$.

\section{Ground Water}

Water samples were collected from nine wells chosen to provide geographic coverage and representative depths ranging from 30 to 123 $\mathrm{ft}$; the results are given in table 9. All wells derive their water from the Boggy Formation. In addition to laboratory analysis of the nine samples, specific conductance and $\mathrm{pH}$ of water from 90 wells (table 1) were determined at the well sites. Values for specific conductance ranged from 105 to 6,500 umho (micromhos per centimeter at $25^{\circ}$ Celsius); the median was 895 umho. Values for $\mathrm{pH}$ ranged from 5.7 to 8.8 .

Specific-conductance measurements provide a means of estimating the concentration of dissolved solids in water where that concentration has not been directly determined. The average ratio of measured dissolved-solids concentration to the specific conductance of ground water in the Blocker area, as determined from data provided by the nine laboratory analyses, is 0.63 . Thus by multiplying the specific conductance by 0.63 , an approximation of the dissolved-solids concentration is obtained. 
Table 6.--Mean, minimum, and maximum values for selected physical properties and chemical constituents of water from Blue Creek

[micromhos $=$ micromhos per centimeter at $25^{\circ}$ Celsius; $\mathrm{ROE}=$ residue on evaporation at $180^{\circ} \mathrm{Celsius;}$ $\mathrm{mg} / \mathrm{L}=$ milligrams per liter; ug/L = micrograms per liter $]$

\begin{tabular}{|c|c|c|c|c|}
\hline Constituent & $\begin{array}{l}\text { Number of } \\
\text { determinations }\end{array}$ & Mean & Minimum & Maximum \\
\hline Specific conductance (micromhos) & 19 & 117 & 54 & 240 \\
\hline $\mathrm{pH}$ (units) & 18 & -- & 6.0 & 8.0 \\
\hline D.issolved solids (ROE) & 19 & 79 & 52 & 150 \\
\hline Hardness $\quad\left(\mathrm{CaCO}_{3}\right)(\mathrm{mg} / \mathrm{L})$ & 19 & 30 & 17 & 59 \\
\hline Bicarbonate $\left(\mathrm{HCO}_{3}\right)(\mathrm{mg} / \mathrm{L})$ & 19 & 20 & 8 & 36 \\
\hline Carbonate $\left(\mathrm{CO}_{3}\right)(\mathrm{mg} / \mathrm{L})$ & 19 & 0 & 0 & 0 \\
\hline Dissolved calcium (Ca) (mg/L) & 19 & 6.4 & 3.4 & 11 \\
\hline Dissolved magnesium $(\mathrm{Mg})(\mathrm{mg} / \mathrm{L})$ & 19 & 3.4 & 1.9 & 7.6 \\
\hline Dissolved sodium (Na) (mg/L) & 19 & 8.9 & 3.0 & 24 \\
\hline Dissolved potassium (K) (mg/L) & 19 & 1.7 & 0.8 & 4.8 \\
\hline Dissolved chloride (Cl) (mg/L) & 19 & 8.2 & 3.2 & 23 \\
\hline Dissolved sulfate $\left(\mathrm{SO}_{4}\right)$ (mg/L) & 19 & 21 & 9.4 & 56 \\
\hline Dissolved fluoride (F) (mg/L) & 19 & 0.1 & 0.0 & 0.2 \\
\hline Dissolved arsenic (As) (ug/L) & 18 & 1 & 0 & 2 \\
\hline Total recoverable arsenic (As) (ug/L) & 8 & 1 & 0 & 8 \\
\hline Dissolved boron (B) $(\mathrm{ug} / \mathrm{L})$ & 16 & 33 & 0 & 70 \\
\hline Total recoverable boron (B) (ug/L) & 9 & 52 & 20 & 110 \\
\hline Dissolved cadmium (Cd) (ug/L) & 16 & 1 & 0 & 8 \\
\hline Total recoverable cadmium (Cd) (ug/L) & 9 & 4 & 0 & 10 \\
\hline Dissolved chromium (Cr) (ug/L) & 16 & 1 & 0 & 10 \\
\hline Total recoverable chromium (Cr) (ug/L) & 9 & 3 & 0 & 10 \\
\hline Dissolved copper (Cu) (ug/L) & 18 & 3 & 0 & 12 \\
\hline Total recoverable copper (Cu) (ug/L) & 9 & 5 & 2 & 10 \\
\hline Dissolved iron $(\mathrm{Fe})(\mathrm{ug} / \mathrm{L})$ & 16 & 178 & 0 & 580 \\
\hline Total recoverable iron (Fe) (ug/L) & 9 & 1,282 & 230 & 2,700 \\
\hline Dissolved lead $(\mathrm{Pb})(\mathrm{ug} / \mathrm{L})$ & 16 & 6 & 0 & 21 \\
\hline Total recoverable lead $(\mathrm{Pb})(\mathrm{ug} / \mathrm{L})$ & 9 & 22 & 0 & 100 \\
\hline Dissolved mercury ( $\mathrm{Hg})(\mathrm{ug} / \mathrm{L})$ & 18 & 0.1 & 0.0 & 1.0 \\
\hline Total recoverable mercury (Hg) (ug/L) & 8 & 0.4 & 0.0 & 2.2 \\
\hline Dissolved manganese (Mn) (ug/L) & 16 & 99 & 0 & 640 \\
\hline Total recoverable manganese (Mn) (ug/L) & 9 & 146 & 40 & 650 \\
\hline Dissolved molybdenum (Mo) (ug/L) & 16 & 0 & 0 & 1 \\
\hline Total recoverable molybdenum (Mo) (ug/L) & 9 & 1 & 0 & 3 \\
\hline Dissolved nickel (Ni) (ug/L) & 16 & 4 & 0 & 17 \\
\hline Total recoverable nickel (Ni) (ug/L) & 9 & 12 & 2 & 50 \\
\hline Dissolved zinc $(\mathrm{Zn})(\mathrm{ug} / \mathrm{L})$ & 16 & 56 & 0 & 420 \\
\hline Total recoverable zinc $(\mathrm{Zn})(\mathrm{ug} / \mathrm{L})$ & 9 & 33 & 0 & 150 \\
\hline Dissolved aluminum (Al) $(\mathrm{ug} / \mathrm{L})$ & 16 & 118 & 0 & 650 \\
\hline Total recoverable aluminum (A1) (ug/L) & 9 & 613 & 0 & 1,600 \\
\hline Dissolved nitrogen (Nitrite as N) (mg/L) & 17 & 0.0 & 0.0 & 0.1 \\
\hline Dissolved nitrogen (Nitrate as N) (mg/L) & 17 & 0.4 & 0.0 & 4.6 \\
\hline
\end{tabular}


Table 7.--Mean, minimum, and maximum values for selected physical properties and chemical constituents of water from Blue Creek tributary

[micromhos $=$ micromhos per centimeter at $25^{\circ}$ Celsius; ROE $=$ residue on evaporation at $180^{\circ}$ Celsius; $\mathrm{mg} / \mathrm{L}=$ milligrams per liter; ug/L = micrograms per liter $]$

\begin{tabular}{|c|c|c|c|c|}
\hline Constituent & $\begin{array}{c}\text { Number of } \\
\text { determinations }\end{array}$ & Mean & Minimum & Maximum \\
\hline Specific conductance (micromhos) & 16 & 102 & 52 & 179 \\
\hline $\mathrm{pH}$ (units) & 16 & --- & 5.5 & 7.8 \\
\hline Dissolved solids (ROE) & 16 & 65 & 41 & 94 \\
\hline Hardness $\left(\mathrm{CaCO}_{3}\right)(\mathrm{mg} / \mathrm{L})$ & 16 & 29 & 10 & 74 \\
\hline Bicarbonate $\left(\mathrm{HCO}_{3}\right)(\mathrm{mg} / \mathrm{L})$ & 16 & 14 & 4 & 40 \\
\hline Carbonate $\left(\mathrm{CO}_{3}\right)(\mathrm{mg} / \mathrm{L})$ & 16 & 0 & 0 & 0 \\
\hline Dissolved calcium (Ca) (mg/L) & 16 & 6.1 & 1.1 & 18 \\
\hline Dissolved magnesium $(\mathrm{Mg})(\mathrm{mg} / \mathrm{L})$ & 16 & 3.3 & 1.8 & 7.1 \\
\hline Dissolved sodium $(\mathrm{Na})(\mathrm{mg} / \mathrm{L})$ & 16 & 7.0 & 3.8 & 12 \\
\hline Dissolved potassium $(\mathrm{K})(\mathrm{mg} / \mathrm{L})$ & 16 & 1.2 & 0.6 & 2.7 \\
\hline Dissolved chloride (C1) (mg/L) & 16 & 7.3 & 3.7 & 13 \\
\hline Dissolved sulfate $\left(\mathrm{SO}_{4}\right)(\mathrm{mg} / \mathrm{L})$ & 16 & 21 & 11 & 39 \\
\hline Dissolved fluoride (F) (mg/L) & 15 & 0.1 & 0.0 & 0.1 \\
\hline Dissolved arsenic (As) (ug/L) & 14 & 0 & 0 & 0 \\
\hline Total recoverable arsenic (As) (ug/L) & 8 & 0 & 0 & 2 \\
\hline Dissolved boron (B) (ug/L) & 15 & 37 & 0 & 160 \\
\hline Total recoverable boron (B) (ug/L) & 9 & 51 & 20 & 90 \\
\hline Dissolved cadmium (Cd) (ug/L) & 15 & 1 & 0 & 4 \\
\hline Total recoverable cadmium (Cd) (ug/L) & 9 & 4 & 0 & 10 \\
\hline Dissolved chromium (Cr) (ug/L) & 15 & 1 & 0 & 10 \\
\hline Total recoverable chromium (Cr) (ug/L) & 9 & 12 & 0 & 100 \\
\hline Dissolved copper (Cu) (ug/L) & 15 & 3 & 0 & 10 \\
\hline Total recoverable copper (Cu) (ug/L) & 9 & 5 & 1 & 10 \\
\hline Dissolved iron (Fe) (ug/L) & 15 & 122 & 10 & 460 \\
\hline Total recoverable iron (Fe) (ug/L) & 9 & 598 & 250 & 790 \\
\hline Dissolved lead $(\mathrm{Pb})(\mathrm{ug} / \mathrm{L})$ & 15 & 8 & 0 & 57 \\
\hline Total recoverable lead $(\mathrm{Pb})(\mathrm{ug} / \mathrm{L})$ & 9 & 28 & 0 & 100 \\
\hline Dissolved mercury $(\mathrm{Hg})(\mathrm{ug} / \mathrm{L})$ & 15 & 0.1 & 0.0 & 0.5 \\
\hline Total recoverable mercury $(\mathrm{Hg})$ (ug/L) & 8 & 0.1 & 0.0 & 0.3 \\
\hline Dissolved manganese (Mn) (ug/L) & 15 & 56 & 6 & 140 \\
\hline Total recoverable manganese (Mn) (ug/L) & 9 & 49 & 10 & 180 \\
\hline Dissolved molybdenum (Mo) (ug/L) & 15 & 0 & 0 & 1 \\
\hline Total recoverable molybdenum (Mo) (ug/L) & 9 & 1 & 0 & 3 \\
\hline Dissolved nickel (Ni) (ug/L) & 15 & 3 & 0 & 8 \\
\hline Total recoverable nickel (Ni) (ug/L) & 9 & 15 & 1 & 50 \\
\hline Dissolved zinc $(\mathrm{Zn})(\mathrm{ug} / \mathrm{L})$ & 15 & 59 & 0 & 700 \\
\hline Total recoverable zinc ( $\mathrm{Zn}$ ) (ug/L) & 9 & 65 & 0 & 490 \\
\hline Dissolved aluminum (Al) (ug/L) & 15 & 86 & 0 & 460 \\
\hline Total recoverable aluminum (Al) (ug/L) & 9 & 353 & 0 & 600 \\
\hline Dissolved nitrogen (Nitrite as $\mathrm{N}$ ) (mg/L) & 14 & 0.0 & 0.0 & 0.0 \\
\hline Dissolved nitrogen (Nitrate as N) (mg/L) & 14 & 4.5 & 0.0 & 61 \\
\hline
\end{tabular}


Table 8.--Mean, minimum, and maximum values for selected physical properties and chemical constituents of water from Mathuldy Creek

[micromhos $=$ micramhos per centimeter at $25^{\circ}$ Celsius; ROE = residue on evaporation at $180^{\circ}$ Celsius; $\mathrm{mg} / \mathrm{L}=$ milligrams per liter; ug $/ \mathrm{L}=$ micrograms per liter ]

\begin{tabular}{|c|c|c|c|c|}
\hline Constituent & $\begin{array}{l}\text { Number of } \\
\text { determinations }\end{array}$ & Mean & Minimum & Maximum \\
\hline Specific conductance (micromhos) & 15 & 284 & 57 & 900 \\
\hline $\mathrm{pH}$ (units) & 15 & --- & 6.5 & 7.9 \\
\hline Dissolved solids (ROE) & 15 & 126 & 50 & 359 \\
\hline Hardness $\left(\mathrm{CaCO}_{3}\right)(\mathrm{mg} / \mathrm{L})$ & 15 & 54 & 23 & 140 \\
\hline Bicarbonate $\left(\mathrm{HCO}_{3}\right)(\mathrm{mg} / \mathrm{L})$ & 15 & 22 & 8 & 72 \\
\hline Carbonate $\left(\mathrm{CO}_{3}\right)(\mathrm{mg} / \mathrm{L})$ & 15 & 0 & 0 & 0 \\
\hline Dissolved calcium (Ca) (mg/L) & 15 & 12 & 5.8 & 32 \\
\hline Dissolved magnesium (Mg) (mg/L) & -15 & 5.7 & 2.0 & 15 \\
\hline Dissolved sodium (Na) (mg/L) & 15 & 14 & 3.0 & 45 \\
\hline Dissolved potassium $(\mathrm{K})(\mathrm{mg} / \mathrm{L})$ & 15 & 2.5 & 0.7 & 6.2 \\
\hline Dissolved chloride (Cl) (mg/L) & 15 & 16 & 2.6 & 87 \\
\hline Dissolved sulfate $\left(\mathrm{SO}_{4}\right)(\mathrm{mg} / \mathrm{L})$ & 15 & 43 & 10 & 110 \\
\hline Dissolved fluoride (F) (mg/L) & 15 & 0.1 & 0.1 & 0.2 \\
\hline Dissolved arsenic (As) (ug/L) & 14 & 1 & 0 & 2 \\
\hline Total recoverable arsenic (As) (ug/L) & 8 & 1 & 0 & 2 \\
\hline Dissolved boron (B) (ug/L) & 13 & 35 & 0 & 60 \\
\hline Total recoverable boron (B) (ug/L) & 8 & 69 & 40 & 90 \\
\hline Dissolved cadmium (Cd) (ug/L) & 14 & 1 & 0 & 6 \\
\hline Total recoverable cadmium (Cd) (ug/L) & 8 & 3 & 0 & 10 \\
\hline Dissolved chromium (Cr) (ug/L) & 13 & 4 & 0 & 20 \\
\hline Total recoverable chromium (Cr) (ug/L) & 8 & 5 & 0 & 20 \\
\hline Dissolved copper (Cu) (ug/L) & 14 & 4 & 0 & 11 \\
\hline Total recoverable copper (Cu) (ug/L) & 8 & 7 & 2 & 15 \\
\hline Dissolved iron (Fe) (ug/L) & 13 & 111 & 10 & 310 \\
\hline Total recoverable iron (Fe) (ug/L) & 8 & 1,908 & 240 & 7,200 \\
\hline Dissolved lead $(\mathrm{Pb})(\mathrm{ug} / \mathrm{L})$ & 13 & 5 & 0 & 21 \\
\hline Total recoverable lead $(\mathrm{Pb})(\mathrm{ug} / \mathrm{L})$ & 8 & 31 & 0 & 100 \\
\hline Dissolved mercury (Hg) (ug/L) & 14 & 0.0 & 0.0 & 0.2 \\
\hline Total recoverable mercury $(\mathrm{Hg})(\mathrm{ug} / \mathrm{L})$ & 8 & 0.1 & 0.0 & 0.3 \\
\hline Dissolved manganese (Mn) (ug/L) & 13 & 144 & 10 & 730 \\
\hline Total recoverable manganese (Mn) (ug/L) & 8 & 280 & 40 & 740 \\
\hline Dissolved molybdenum (Mo) (ug/L) & 13 & 0 & 0 & 2 \\
\hline Total recoverable molybdemum (Mo) (ug/L) & 8 & 1 & 0 & 3 \\
\hline Dissolved nickel (Ni) (ug/L) & 13 & 6 & 0 & 28 \\
\hline Total recoverable nickel (Ni) (ug/L) & 8 & 22 & 5 & 50 \\
\hline Dissolved zinc $(\mathrm{Zn})(\mathrm{ug} / \mathrm{L})$ & 13 & 33 & 0 & 160 \\
\hline Total recoverable zinc $(\mathrm{Zn})$ (ug/L) & 8 & 45 & 10 & 130 \\
\hline Dissolved alumimum (Al) $(\mathrm{ug} / \mathrm{L})$ & 13 & 109 & 0 & 610 \\
\hline Total recoverable aluminum (Al) (ug/L) & 7 & 627 & 0 & 1,500 \\
\hline Dissolved nitrogen (Nitrite as N) (mg/L) & 14 & 0.0 & 0.0 & 0.0 \\
\hline Dissolved nitrogen (Nitrate as N) (mg/L) & 14 & 0.5 & 0.0 & 4.6 \\
\hline
\end{tabular}


Table 9.--Quality of water from selected wells

$\left[\right.$ micromhos $=$ micromhos per centimeter at $25^{\circ} \mathrm{Celsius;} \mathrm{ROE} \mathrm{=} \mathrm{residue} \mathrm{on} \mathrm{evaporation} \mathrm{at} 180^{\circ} \mathrm{Celsius}$; mg/L, milligrams per liter; ug/L, micrograms per liter ]

\begin{tabular}{|c|c|c|c|c|c|}
\hline Number on trilinear diagram (fig. 7) & 1 & 2 & 3 & 4 & 5 \\
\hline We11 number & $06 \mathrm{~N}-16 \mathrm{E}-01$ DDA 1 & $07 \mathrm{~N}-16 \mathrm{E}-13 \mathrm{DCB} 2$ & $07 \mathrm{~N}-16 \mathrm{E}-23 \mathrm{CBB} 2$ & $07 \mathrm{~N}-16 \mathrm{E}-25$ ACC 1 & $07 \mathrm{~N}-16 \mathrm{E}-25 \mathrm{BAA}$ \\
\hline Date sampled (year-month-day) & $76-08-23$ & $76-08-19$ & $76-08-19$ & $76-08-18$ & $76-08-18$ \\
\hline Depth of well (feet) & 74 & 123 & 65 & 72 & 97 \\
\hline Aquifer & Boggy Formation & Boggy Formation & Boggy Formation & Boggy Formation & Boggy Formation \\
\hline Water temperature $\left({ }^{\circ} \mathrm{Ce} 1\right.$ sius $)$ & 19.5 & 19.5 & 20 & 25 & 19.5 \\
\hline Specific conductance (micramhos) & 970 & 1,390 & 620 & 470 & 930 \\
\hline pH (units) & 7.0 & 7.0 & 6.9 & 8.8 & 7.8 \\
\hline Carbon dioxide $\left(\mathrm{CO}_{2}\right)(\mathrm{mg} / \mathrm{L})$ & 64 & 69 & 53 & .7 & 13 \\
\hline Alkalinity as $\mathrm{CaCO}_{3}(\mathrm{mg} / \mathrm{L})$ & 327 & 354 & 215 & 240 & 417 \\
\hline Total acidity as $\mathrm{CaCO}_{3}(\mathrm{mg} / \mathrm{L})$ & 20 & 5.0 & 10 & .0 & 5.0 \\
\hline Bicarbonate $\left(\mathrm{HCO}_{3}\right)(\mathrm{mg} / \mathrm{L})$ & 399 & 431 & 262 & 292 & 509 \\
\hline Carbonate $\left(\mathrm{CO}_{3}\right)(\mathrm{mg} / \mathrm{L})$ & 0 & 0 & 0 & 0 & 0 \\
\hline Hardness (Ca plus $\mathrm{Mg}$ ) (mg/L) & 320 & 620 & 170 & 12 & 70 \\
\hline Noncarbonate hardness (mg/L) & 0 & 270 & 0 & 0 & 14 \\
\hline Dissolved calcium (Ca) (mg/L) & 68 & 100 & 51 & 3.7 & 2.6 \\
\hline Dissolved magnesium $(\mathrm{Mg})(\mathrm{mg} / \mathrm{L})$ & 36 & 90 & 9.5 & .7 & 1.8 \\
\hline Dissolved sodiun $(\mathrm{Na})(\mathrm{mg} / \mathrm{L})$ & 82 & 88 & 67 & 110 & 220 \\
\hline Dissolved potassium $(\mathrm{K})(\mathrm{mg} / \mathrm{L})$ & 1.6 & 2.9 & 1.0 & .4 & .7 \\
\hline Dissolved chloride $(\mathrm{Cl})(\mathrm{mg} / \mathrm{L})$ & 30 & 9.3 & 35 & 3.4 & 47 \\
\hline Dissolved sulfate $\left(\mathrm{SO}_{4}\right)(\mathrm{mg} / \mathrm{L})$ & 140 & 400 & 56 & 7.8 & 18 \\
\hline Dissolved fluoride $(\mathrm{F})(\mathrm{mg} / \mathrm{L})$ & 0.3 & .5 & .3 & .4 & .6 \\
\hline Dissolved silica $\left(\mathrm{SiO}_{2}\right)(\mathrm{mg} / \mathrm{L})$ & 18 & 19 & 14 & 19 & 18 \\
\hline Dissolved arsenic (As) (ug/L) & 0 & 1 & 1 & 0 & 0 \\
\hline Dissolved barium ( $\mathrm{Ba})(\mathrm{ug} / \mathrm{L})$ & 0 & 0 & 200 & 0 & 0 \\
\hline Dissolved boron (B) (ug/L) & 90 & 80 & 50 & 90 & 220 \\
\hline Dissolved cadmium (Cd) (ug/L) & 3 & 4 & 2 & 1 & 3 \\
\hline Dissolved chromium (Cr) (ug/L) & 0 & 0 & 0 & 0 & 10 \\
\hline Dissolved cobalt $(\mathrm{Co})(\mathrm{ug} / \mathrm{L})$ & 0 & 0 & 2 & 1 & 1 \\
\hline Dissolved copper (Cu) (ug/L) & 0 & 1 & 0 & 7 & 0 \\
\hline Dissolved iron (Fe) (ug/L) & 840 & 270 & 1,300 & 40 & 70 \\
\hline Dissolved lead $(\mathrm{Pb})(\mathrm{ug} / \mathrm{L})$ & 20 & 24 & 12 & 11 & 30 \\
\hline Dissolved manganese $(\mathrm{Mn})(\mathrm{ug} / \mathrm{L})$ & 240 & 260 & 1,100 & 10 & 10 \\
\hline Dissolved molybdenum (Mo) (ug/L) & 0 & 0 & 0 & 0 & 0 \\
\hline Dissolved nickel (Ni) (ug/L) & 1 & 0 & 3 & 0 & 0 \\
\hline Dissolved vanadium (V) (ug/L) & .7 & .0 & .6 & 1.7 & 1.5 \\
\hline Dissolved $z$ inc $(\mathrm{Zn})$ (ug/L) & 30 & 70 & 330 & 10 & 0 \\
\hline Dissolved aluminum (A1) (ug/L) & 10 & 10 & 10 & 10 & 10 \\
\hline Dissolved lithium (Li) (ug/L) & 30 & 60 & 30 & 20 & 40 \\
\hline Dissolved selenium (Se) (ug/L) & 0 & 0 & 0 & 0 & 0 \\
\hline Dissolved solids (ROE) (mg/L) & 588 & 983 & 354 & 297 & 562 \\
\hline Dissolved solids (sum) (mg/L) & 574 & 923 & 366 & 290 & 560 \\
\hline
\end{tabular}


Number on trilinear diagram (fig. 7) Well number

Date sampled (year-month-day)

Depth of well (feet)

Aquifer

Water temperature $\left({ }^{\circ} \mathrm{Cel}\right.$ sius)

Specific conductance (micramhos)

$\mathrm{pH}$ (units)

Carbon dioxide $\left(\mathrm{CO}_{2}\right)(\mathrm{mg} / \mathrm{L})$

Alkalinity as $\mathrm{CaCO}_{3}$ (mg/L)

Total acidity as $\mathrm{CaCO}_{3}(\mathrm{mg} / \mathrm{L})$

Bicarbonate $\left(\mathrm{HCO}_{3}\right)(\mathrm{mg} / \mathrm{L})$

Carbonate $\left(\mathrm{CO}_{3}\right)(\mathrm{mg} / \mathrm{L})$

Hardness (Ca plus $\mathrm{Mg}$ ) (mg/L)

Noncarbonate hardness (mg/L)

Dissolved calcium (Ca) (mg/L)

Dissolved magnesium (Mg) (mg/L)

Dissolved sodium (Na) (mg/L)

Dissolved potassium $(\mathrm{K})(\mathrm{mg} / \mathrm{L})$

Dissolved chloride (C1) (mg/L)

Dissolved sulfate $\left(\mathrm{SO}_{4}\right)$ (mg/L)

Dissolved fluoride (F) (mg/L)

Dissolved silica $\left(\mathrm{SiO}_{2}\right)(\mathrm{mg} / \mathrm{L})$

Dissolved arsenic (As) (ug/L)

Suspended arsenic (As) (ug/L)

Dissolved barium (Ba) (ug/L)

Dissolved boron (B) (ug/L)

Dissolved cadmium (Cd) (ug/L)

Dissolved chromium (Cr) (ug/L)

Dissolved cobalt (Co) (ug/L)

Dissolved copper (Cu) (ug/L)

Dissolved iron (Fe) (ug/L)

Dissolved lead ( $\mathrm{Pb})(\mathrm{ug} / \mathrm{L}$ )

Dissolved manganese (Mn) (ug/L)

Dissolved molybdenum (Mo) (ug/L)

Dissolved nickel (Ni) (ug/L)

Dissolved vanadium (V) (ug/L)

Dissolved zinc ( $\mathrm{Zn})(\mathrm{ug} / \mathrm{L})$

Dissolved aluminum (AI) (ug/L)

Dissolved lithium (Li) (ug/L)

Dissolved selenium (Se) (ug/L)

Dissolved solids (ROE) (mg/L)

Dissolved solids (sum) (mg/L)
6

07N-16E-26 ABA 1

76-08-20

30

Boggy Formation

$$
18.5
$$

2,690

7.6

14

276

10

337

0

790

520

120

120

330

3.5

190

870

.6

12

0

$--$

0

110

1

10

0



60

4

30

0

1

\section{0}

60

10

90

1

2,010

1,810

\section{7}

07N-17E-17 CCC 1

76-08-19

84

Boggy Formation

19.5

740

7.2

37

298

10

363

0

140

0

33

14

110

1.7

49

32

.3

22

0

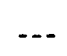

100

100

5

0

0

13

20

37

50

0

0

.0

60

10

30

0

434

442
8

$07 N-17 E-20$ CCC 2

76-08-19

102

Boggy Formation

19.0

660

7.9

6.8

279

.0

340

0

69

0

18

5.9

130

1.0

41

14

.4

20

0

--.

100

100

8

0

0

0

20

49

20

0

2

.7

30

10

30

0

397

398
9

07N-17E-30 AAB 1

76-08-19

46

Boggy Formation

24.0

520

7.2

32

257

10

313

0

160

0

31

19

61

1.5

11

14

.5

20

0

0

100

80

3

0

0

28

110

25

50

0

0

2.0

60

20

30

0

303

313 
The trilinear diagram (fig. 7) shows that water from wells 2, 4, 7 , and 9 is of the sodium type; no cation was dominant in water from the other five wells. The dominant anion, except for water from wells 5 and 8 , is bicarbonate.

\section{Constituent Concentrations}

The dissolved-solids concentrations ranged from 297 to $2,020 \mathrm{mg} / \mathrm{L}$ in the 9 wells (table 9); no relationship between dissolved-solids concentrations and well depth or geographic distribution is apparent. None of the maximum contaminant levels for drinking water for the toxic metals were exceeded.

\section{SUSPENDED SEDIMENT}

The amount and size of suspended sediment carried by streams in the Blocker area depends on several interrelated conditions including climate, geology and soils, topography, land use, and land cover. Climatic conditions of particular significance are distribution and intensity of rainfall. Because much of the precipitation falls as thundershowers of varying intensity during the spring and early summer months, the largest sediment loads can be expected at that time. The two major soil associations in most of the area are that DennisParsons-Bates and the Enders-Hector-Hartsells associations (Shingleton, 1971). The Dennis-Parsons-Bates is present in the broad, grass-covered valleys where slopes are generally less than 5 percent. The Enders-Hector-Hartsells association occurs on the forested uplands where slopes range from 5 to 60 percent. Soils in the area are derived from shale-siltstone-sandstone bedrock and primarily are fine sandy loams.

Suspended sediment samples from streams in the Blocker area represent the conditions at the time the samples were collected. Samples were collected irrespective of stream stage, either rising or falling, and do not necessarily correspond to peak discharge. Concentrations were determined from samples collected by using depth integrating samplers, usually representing several verticals in the cross section. Suspended sediment concentration is the velocity-weighted concentration of suspended sediment in the sampled zone expressed as milligrams of dry sediment per liter of water-sediment mixture. Each vertically sampled zone extended from the water surface to a point approximately $0.3 \mathrm{ft}$ above the stream bed, a limit established by nozzle and sampler configuration. 


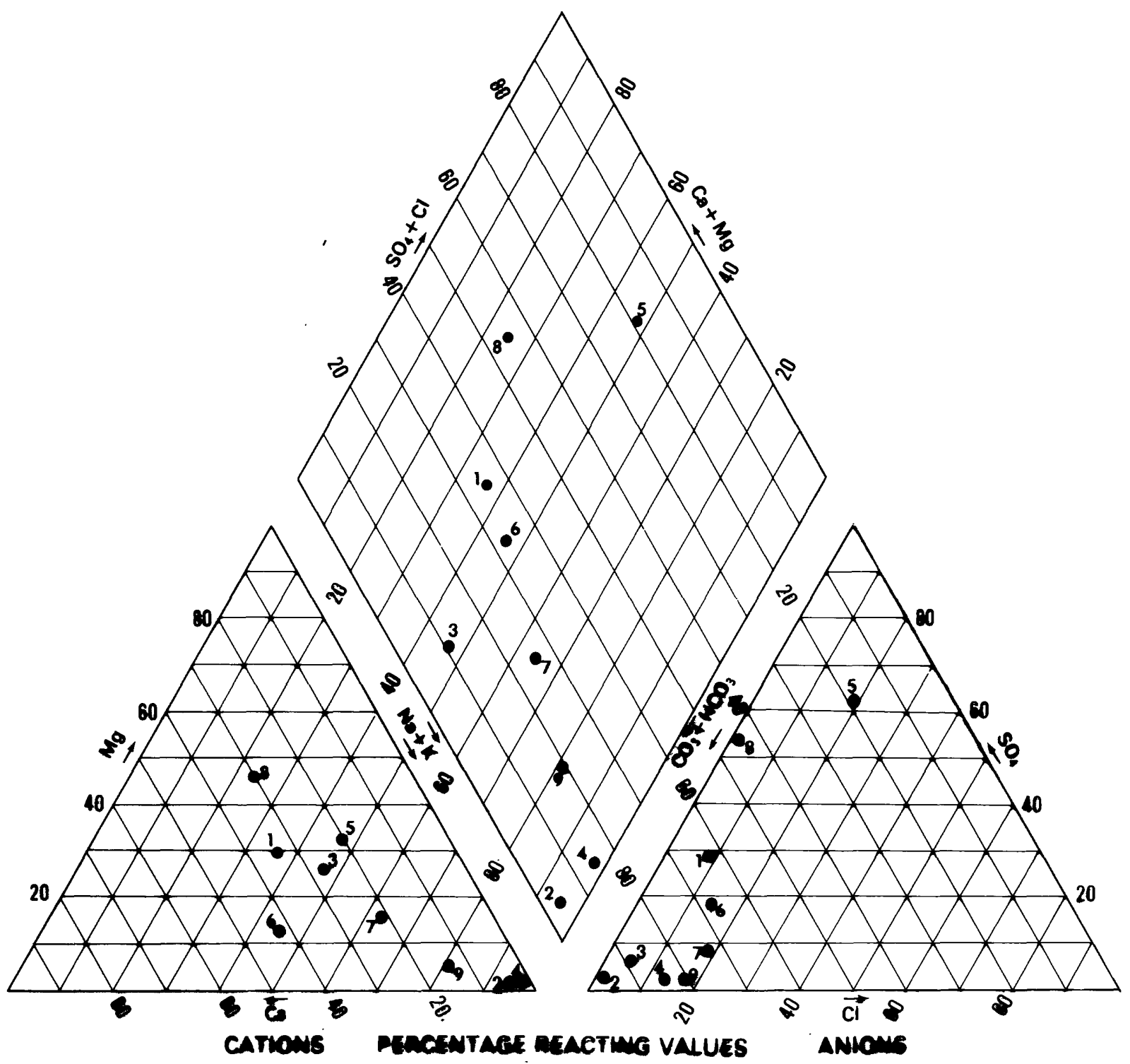

Figure 7.- Trilinas diagram for water from selocted wells. Numbers refer to woll lacations shawn on Plate 2. 
The relationship between stream discharge and suspended-sediment discharge is shown in figure 8. The Blue Creek data shows the best relationship; the relationships for Blue Creek tributary and Mathuldy Creek are not well defined. Some of the scatter of the points is attributed to plotting data from both rising and falling stages. Rising-stage discharge would be expected to transport significantly greater quantities of suspended sediment. The frequency of sampling is periodic; that is, samples are not necessarily collected during each period of runoff at each site. Although discharge of Blue Creek has exceeded $80 \mathrm{ft} / \mathrm{s}$, no sediment data are presently available to define the relationship at greater discharges.

Particle-size determinations separate the sediment into two size groups - diameters larger or smaller than $0.062 \mathrm{~mm}$ (millimeter). Particles with diameters larger than $0.062 \mathrm{~mm}$ are classed as sand; particles with diameters smaller than $0.062 \mathrm{~mm}$ are classed as silt-clay. As expected in an area where bedrock is predominantly shale and the soil is mostly fine sandy loam, the median of the silt-clay fraction ranged from 86 to 96 percent (table 10). Available suspended-sediment data are given in tables 11-13.

\section{STREAM-BED MATERIAL}

Samples of stream-bed materials were analyzed for selected common ions, trace constituents, and nutrients (table 14). The number of sampling points within a cross section or reach depends on the width of the flow at the time of sampling. The values represent only the measured range of background conditions.

\section{WATER DEVELOPMENT AND USE}

Wells are the only presently (1981) used source of water for human consumption in the Blocker area. For this study, 103 wells were inventoried during May and June 1976; a few additional wells may have been drilled since that time. Approximately 20 additional wells were visited but not inventoried, generally because the well depth or depth to water could not be determined. As stated previously, well yields are probably less than $5 \mathrm{gal} / \mathrm{min}$. Greater yields might be obtained from deeper wells but below a depth of 250-300 ft the water is likely to be brackish or salty. Total ground water use is estimated to be about 8,000 gal/d.

Streams in the area are used only to water livestock. Because these streams are dry at least parts of most years, ponds have been constructed to supply stock water. The amount of water used for stock watering is estimated to be about 5,000 $\mathrm{gal} / \mathrm{d}$.

Because they are ephemeral, streams in the area provide only limited habitat for wildlife; they do not support fish of interest to fishermen. A few of the larger ponds have been stocked with fish and some may be used occasionally for swimming. 


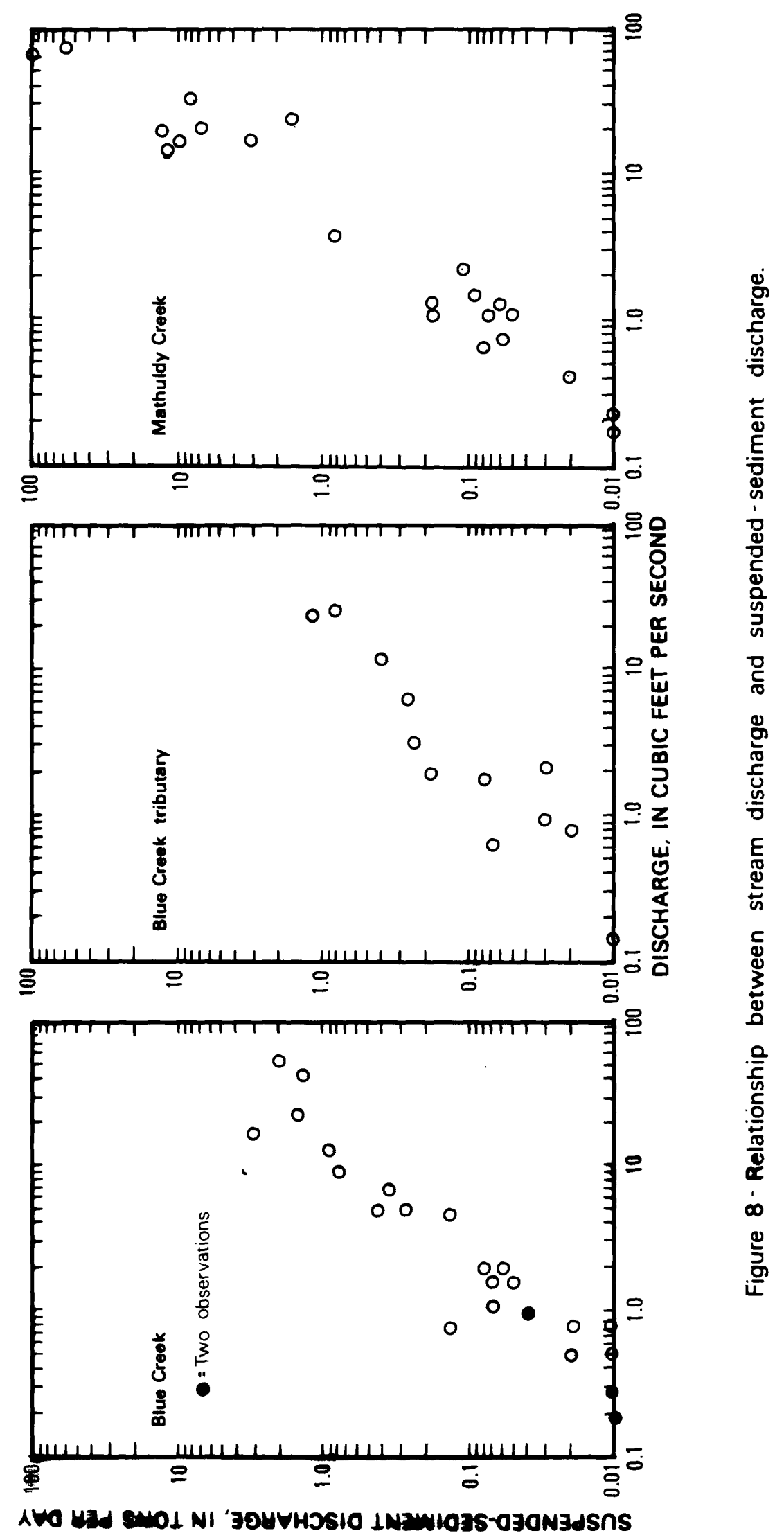




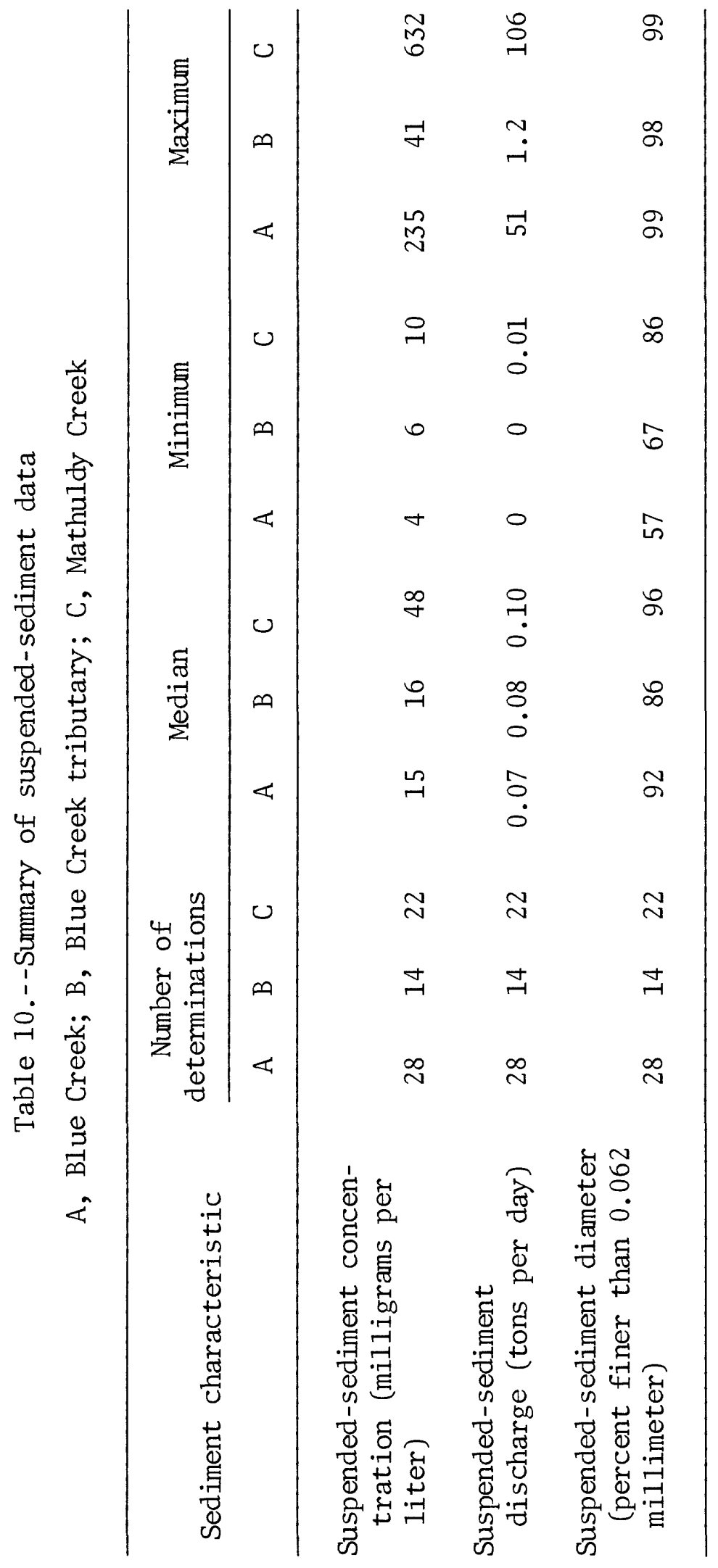


Table 11.--Suspended-sediment data for Blue Creek (station 07232010)

\begin{tabular}{|c|c|c|c|c|}
\hline Date & $\begin{array}{l}\text { Instantaneous } \\
\text { streamflow } \\
\text { (cubic feet } \\
\text { per second) }\end{array}$ & $\begin{array}{l}\text { Suspended } \\
\text { sediment } \\
\text { concentration } \\
\text { (milligrams } \\
\text { per liter) }\end{array}$ & $\begin{array}{c}\text { Suspended } \\
\text { sediment } \\
\text { discharge } \\
\text { (tons per } \\
\text { day) }\end{array}$ & $\begin{array}{l}\text { Percentage of } \\
\text { suspended sedi- } \\
\text { ment finer than } \\
0.062 \text { millimeter }\end{array}$ \\
\hline
\end{tabular}

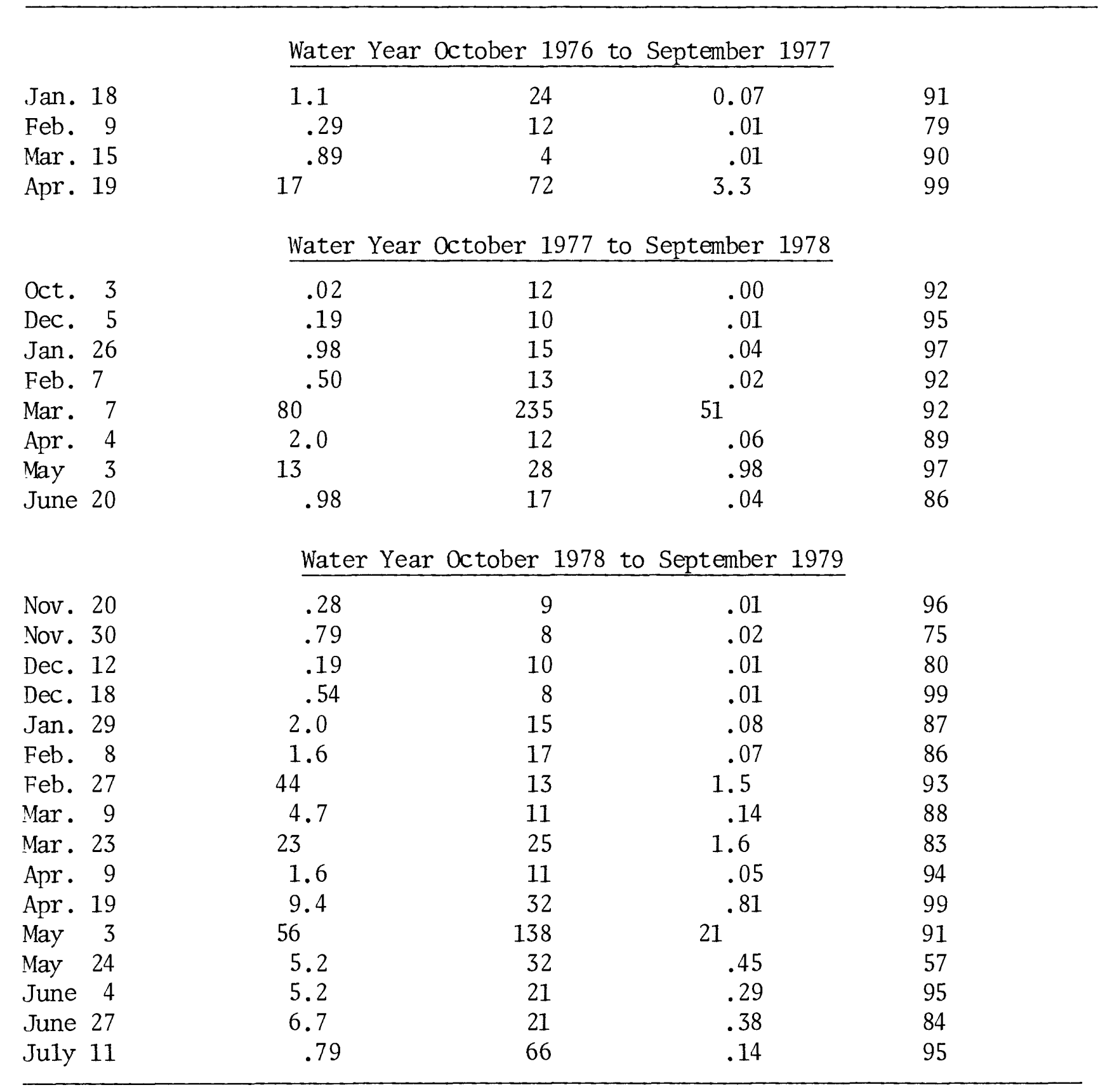


Table 12.--Suspended-sediment data for Blue Creek tributary (station 07232008)

\begin{tabular}{ccccc}
\hline Instantaneous & Suspended \\
streamflow & sediment \\
(cubic feet & concentration \\
(milligrams & $\begin{array}{c}\text { Suspended } \\
\text { sediment } \\
\text { per second) }\end{array}$ & $\begin{array}{c}\text { Percentage of } \\
\text { (tons per } \\
\text { per liter) }\end{array}$ & $\begin{array}{c}\text { day) } \\
\text { ment finer than }\end{array}$ \\
& & 0.062 millimeter \\
\hline
\end{tabular}

Water Year October 1978 to September 1979

Dec. 11

0.09

11

0.00

73

Dec. 18

.14

27

.01

96

Jan. 30

.97

11

.03

74

Feb. 8

.64

41

.07

93

Feb. 27

25

13

.88

88

Mar. 8

2.1

6

.03

80

Mar. 23

12

13

.42

67

Apr. 10

.82

10

.02

73

Apr. 19

3.3

28

.25

98

May 3

24

18

1.2

96

May 25

2.0

36

.19

84

June 4

1.8

17

.08

88

June 26

6.5

16

.28

79

July 11

.06

18

.00

95 
Table 13.--Suspended-sediment data for Mathuldy Creek (station 07232029).

\begin{tabular}{|c|c|c|c|c|}
\hline Date & $\begin{array}{l}\text { Instantaneous } \\
\text { streamflow } \\
\text { (cubic feet } \\
\text { per second) }\end{array}$ & $\begin{array}{l}\text { Suspended } \\
\text { sediment } \\
\text { concentration } \\
\text { (milligrams } \\
\text { per liter) }\end{array}$ & $\begin{array}{l}\text { Suspended } \\
\text { sediment } \\
\text { discharge } \\
\text { (tons per } \\
\text { day) }\end{array}$ & $\begin{array}{l}\text { Percentage of } \\
\text { suspended sedi- } \\
\text { ment finer than } \\
0.062 \text { millimeter }\end{array}$ \\
\hline
\end{tabular}

Water Year October 1976 to September 1977

Mar. 15

Apr. 19

Jan. 26

Mar. 7

Apr. 5

May 3

June 21

Nov. 30

Jan. 29

Feb. 14

Feb. 23

Mar. 9

Mar. 22

Apr . 6

Apr. 20

May 3

May 24

June 4

June 21

June 21

July 13
1.5

22
22

27

0.09

92

86

Water Year October 1977 to September 1978

$\begin{array}{crcc}.40 & 19 & .02 & 97 \\ 2.2 & 18 & .11 & 92 \\ 62 & 632 & 106 & 97 \\ 1.1 & 22 & .07 & 92 \\ 18 & 272 & 13 & 99 \\ .23 & 10 & .01 & 89\end{array}$

Water Year October 1978 to September 1979

$\begin{array}{crcr}.18 & 22 & .01 & 97 \\ .74 & 32 & .06 & 93 \\ 3.6 & 88 & .86 & 95 \\ 20 & 131 & 7.1 & 90 \\ 1.3 & 16 & .06 & 97 \\ 32 & 96 & 8.3 & 93 \\ 1.1 & 16 & .05 & 100 \\ 1.1 & 60 & .18 & 98 \\ 17 & 72 & 3.3 & 98 \\ 1.3 & 51 & .18 & 91 \\ .65 & 44 & .08 & 98 \\ 16 & 244 & 10 & 96 \\ 70 & 309 & 58 & 91 \\ .06 & 55 & .01 & 97\end{array}$


Table 14.--Selected trace constituents and nutrients in stream-bottom material

[A, Blue Creek; B, Blue Creek tributary; C, Mathuldy Creek. All values are amounts recoverable from botton material. All values are in micrograms per gram except nitrogen and phosphorus which are in milligrams per kilogram]

\begin{tabular}{|c|c|c|c|c|c|c|c|c|c|c|c|}
\hline \multicolumn{2}{|c|}{ Site } & \multirow{2}{*}{$\begin{array}{l}\text { Date } \\
3,1978\end{array}$} & \multirow{2}{*}{$\begin{array}{c}\text { Time } \\
1630\end{array}$} & \multirow{2}{*}{$\begin{array}{c}\text { Nitrogen } \\
\left(\mathrm{NO}_{2}+\mathrm{NO}_{3}\right)\end{array}$} & \multirow{2}{*}{$\begin{array}{c}\text { Nitrogen } \\
(\mathrm{NH}) \\
\ldots\end{array}$} & \multirow{2}{*}{$\begin{array}{c}\begin{array}{c}\text { Nitrogen } \\
(\mathrm{NH}+ \\
\text { organic) }\end{array} \\
\ldots . .\end{array}$} & \multirow{2}{*}{ Phosphorus } & \multirow{2}{*}{$\frac{\text { Aluminum }}{1,800}$} & \multirow{2}{*}{$\frac{\text { Arsenic }}{33}$} & \multirow{2}{*}{$\frac{\text { Cadmium }}{0}$} & \multirow{2}{*}{ Chromium } \\
\hline A & May & & & & & & & & & & \\
\hline B & Oct. & 26,1978 & 1600 & 2.1 & 8.6 & 100 & 120 & -.. & 1 & 0 & 0 \\
\hline A & Apr. & 9, 1979 & 1550 & 2.8 & 13 & 258 & 830 & 1,700 & 29 & 0 & 12 \\
\hline A & July & 11,1979 & 1725 & .0 & 26 & 300 & 630 & 15 & 31 & 0 & 0 \\
\hline B & Apr. & 10,1979 & 0900 & 3.2 & 9.7 & 243 & 780 & 2,100 & 30 & 0 & 22 \\
\hline B & July & 11,1979 & 1455 & .0 & 18 & 334 & 350 & 5 & 22 & 0 & 0 \\
\hline $\mathrm{C}$ & May & 3, 1978 & 0815 & -- & -- & 333 & 333 & 1,600 & 56 & 0 & 8 \\
\hline $\mathrm{C}$ & Apr . & 6, 1979 & 0855 & 5.8 & 14 & 306 & 810 & 2,300 & 28 & 0 & 11 \\
\hline $\mathrm{C}$ & July & 13,1979 & 0830 & 3.7 & 11 & 1,100 & 770 & 10 & 36 & 0 & 0 \\
\hline
\end{tabular}

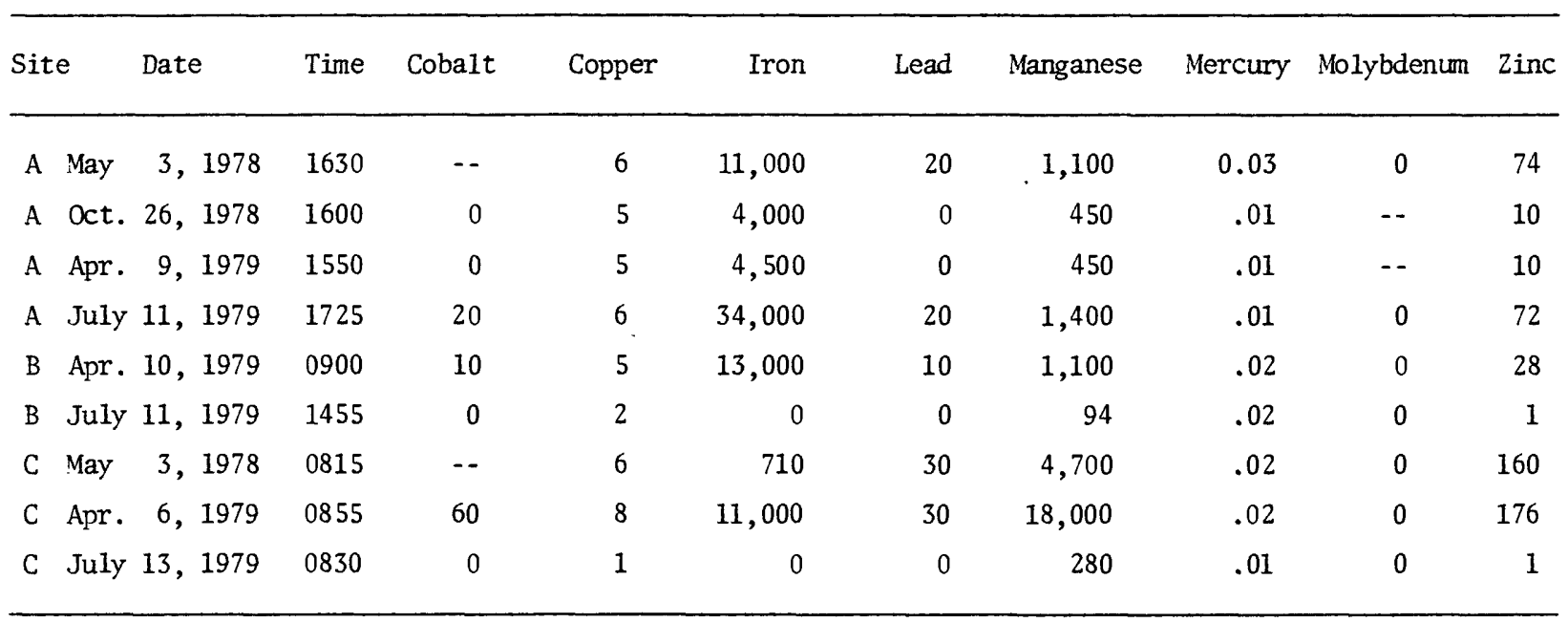




\section{POTENTIAL HYDROLOGIC EFFECTS OF SURFACE MINING}

Surface mining for coal and subsequent reclamation in the Blocker area may cause either beneficial or adverse changes in the hydrologic system; these changes may be either short or long term. The following description of the coal-mining process as practiced in 0klahoma is summarized from Johnson (1974) to show how some of these changes may occur.

A surface-mining operation ( $f$ ig. 9) involves digging a trench to expose the coal bed which is then removed. As each succeeding cut is made, the overburden or spoil is placed into the cut previously excavated. Successive cuts are mined until the overburden thickness becomes so great the coal can no longer be mined profitably. The final cut leaves an open trench bounded by the last spoil pile on one side and the undisturbed highwall on the other. The ridges of spoil are graded to a rolling topography and revegetated with pasture grasses. The final cut and other depressions partly fill with water from precipitation and ground-water seepage. The revegetated area usually is not grazed until the grass has become well established.

A readily apparent change in the hydrologic system resulting from surface mining is the creation of additional storage of water in the last mine cut shown in figure 9. A mine pond $0.5 \mathrm{mi}$ long, $200 \mathrm{ft}$ wide, and containing $30 \mathrm{ft}$ of water has a volume of 360 acre-ft. Such a pond would provide a habitat for aquatic and semiaquatic wildlife and could be stocked with fish. Also water from mine ponds may be used for stock, domestic, municipal, and irrigation supply. 

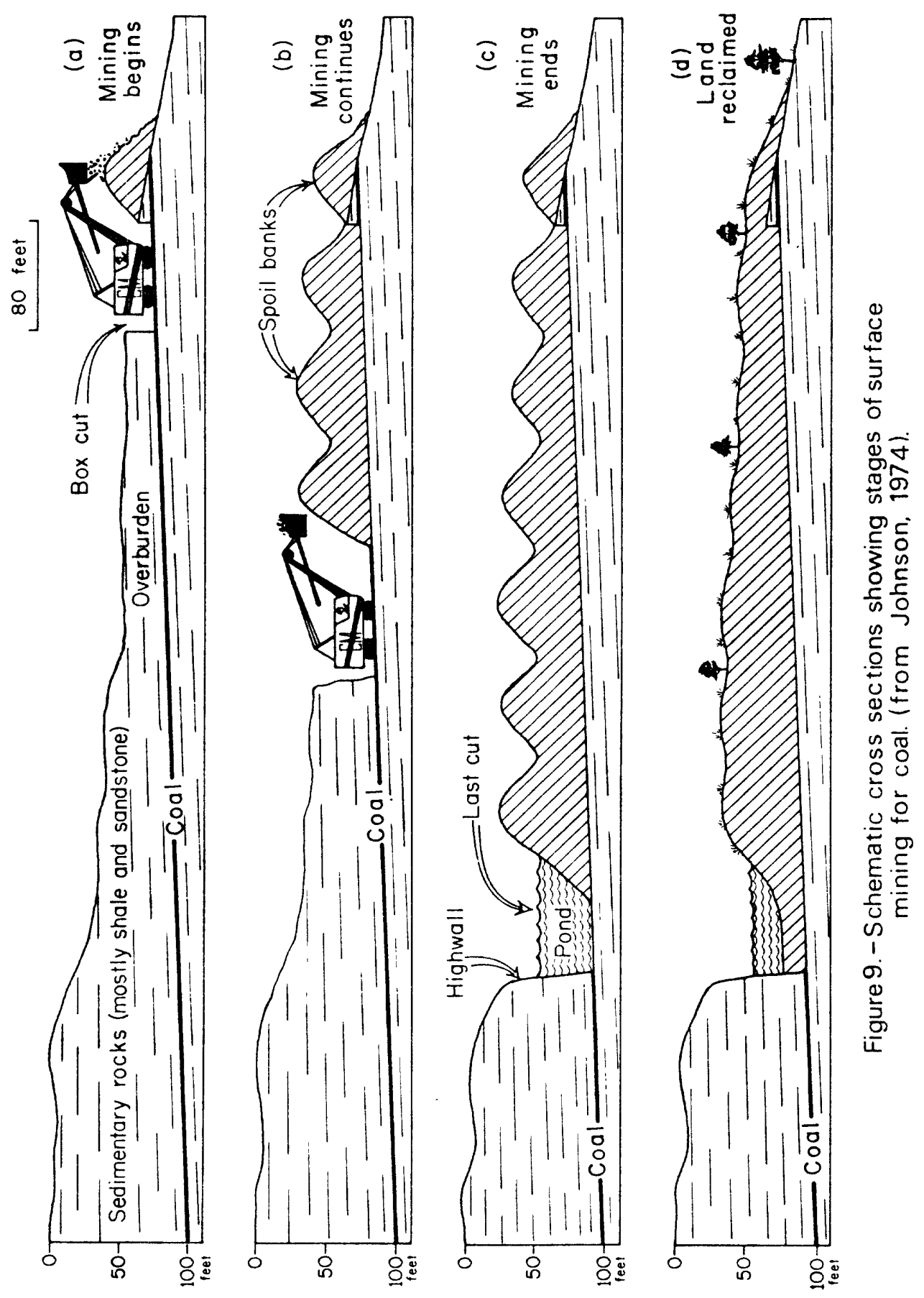
In addition to increasing the storage of water in mine ponds, other potential changes in the hydrologic system include: (1) changes in permeability and ground-water storage, (2) changes in runoff and streamflow characteristics, (3) changes in drainage patterns, (4) changes in the chemical quality of water, and (5) changes in sediment discharge of streams.

1. Changes in permeability and ground-water storage:

Overburden in the Blocker area consists of shale with some siltstone and a few thin beds of sandstone. These rocks have minimal porosity and permeability. During mining, however, the overburden is broken and shattered to form spoil with many openings that facilitate the entry, movement, and storage of water from precipitation or the adjacent mine pond. The water stored in the spoil may (a) move into the adjacent bedrock, (b) be slowly discharged into streams, and (c) be used by plants. Where it is sufficiently permeable the spoil also may be a source of water to wells.

2. Changes in runoff and streamflow characteristics:

Observations in some parts of the 0klahoma coal field show that if appropriate reclamation procedures are used, grasses on the reclaimed spoil may be more lush and have a denser growth than the original native vegetation. The denser plant growth retards overland storm runoff so that it has more time to soak into the soil and, as a consequence, less water reaches the streams during times of normally high runoff. Conversely, ground water stored in the spoil may be slowly released to streams thereby sustaining streamflow during dry periods. The overall resulting changes in streamflow would be reduced peak discharges and extended periods of low flow. However, in the Blocker area, peak discharges of the larger streams probably would not be affected significantly because the mined areas would be only a small fraction of the total area of the drainage basins.

3. Changes in drainage patterns:

To prevent storm runoff from entering surface-mine ponds during mining operations, some diversions of stream channels may be needed. These diversions would be of limited extent, and if appropriately constructed, should not have any significant effect on the overall hydrologic system. 
4. Changes in chemical quality of water:

Minerals in the overburden and coal are in equilibrium with their environment as long as that environment is not changed. Mining, however, disturbs that equilibrium and the minerals react with various chemical components of their new environment such as water, oxygen, and plant acids. For example, pyrite, which is commonly associated with coal, reacts with water and oxygen to release iron and sulfate and to increase the acidity of the water. Other chemical reactions, especially in the presence of pyrites, may result in the release of various trace elements such as lead, copper, and zinc, that may be present in the coal. As a consequence of these reactions, new and generally undesirable chemicals may be released to the ground and surface waters. The kinds and amounts of these chemicals and their overall effect on the hydrologic system in the Blocker area cannot be determined from the available data.

Strip mining of Federally-owned coal in the blocker area presumably would take place on the south and west flanks of Kinta anticline (pl. 1). The movement of ground water in these areas is toward the south and west, based on the potentiometric map of the area (pl. 2), away from the town of Blocker where wells are concentrated. Thus, the likelihood of the quality of ground water in Blocker being affected appears minimal.

5. Changes in sediment discharge:

Disruption of the land surface during mining operations and before the spoil is fully reclaimed, will increase the amount of sediment available to the streams. However, if appropriate mining practices are followed, such as the use of settling ponds, the amount of sediment added to the streams could be reduced. Likewise, the time available for sediment to be added to the steams can be reduced if revegetation of the spoil is done rapidly and effectively.

In summary, effects of mining in the Blocker area would be an increase in water storage in mine ponds and possibly an increase in the amount and duration of streamflow during normally dry periods. Changes in drainage patterns would be of limited extent and not likely to significantly affect the hydrologic system of the area. Increases in sediment loads of streams should be of limited amount and duration if appropriate mining and reclamation practices are followed. Impairment of the chemical quality of ground water, if it occurs, would be of limited extent and should not water supplies in the town of Blocker. The kinds of dissolved minerals added to streams depends on the mineralogy of the overburden and the coal; the amounts would, to some extent, depend on mining and reclamation practices. 
The water resources of the Blocker area are limited. Wells yield enough water for household or stock supplies but larger amounts are not available because of the limited permeability of the rocks. Streams in the area commonly are dry about 3 months each year, and therefore, they are not a dependable source of water and they provide only limited habitat for wildlife. Ponds are relied on to furnish water for stock during dry periods.

The chemical quality of ground water is extremely variable; the causes of these variations are not known but the water is generally suitable for household use. The available water-quality data for streams in the area indicate that man has not greatly affected the hydrologic environment. Surface mining for coal undoubtedly will have some effect on the environment. The most likely deleterious effects are increased sediment loads in streams and increased mineralization of stream waters. However, these effects should be of only limited extent and duration if appropriate mining and reclamation practices are followed. 
Dane, C.H., Rothrock, H.E., and Williams, J.S., 1938, Geology and fuel resources of the southern part of the Oklahoma coal field: U.S. Geological Survey Bulletin 874-C, pp. 151-253.

Hem, J.D., 1970, Study and interpretation of the chemical characteristics of natural waters: U.S. Geological Water-Supply Paper 1473, (2d ed.), $363 \mathrm{p}$.

Holbrook, Stanley, 1974, Climate in Soil survey of Pittsburg County, Oklahoma: U.S. Department of Agriculture, Soil Conservation Service, pp. 1-3.

Johnson, K.S., 1974, Maps and description of disturbed and reclaimed surface-mined coal lands in eastern Oklahoma: Oklahoma Geological Survey Map GM-17, 3 sheets, scale 1:125,000.

Johnson, K.S., Branson, C.C., Curtis, N.M., Jr., Ham, W.E., Marcher, M.V., and Roberts, J.F., 1972, Geology and earth resources of Oklahoma: Oklahoma Geological Survey Educational Publication 1, $8 \mathrm{p}$.

Marcher, M.V., 1969, Reconnaissance of the water resources of the Fort Smith quadrangle, east-central Oklahoma: Oklahoma

Geological Survey Hydrologic Atlas 1, 4 sheets, scale 1:250,000.

Oklahoma Water Resources Board, 1970, Appraisal of the water and related land resources of Oklahoma, Region Seven: Oklahoma Water Resources Board, $141 \mathrm{p}$.

Piper, A.M., 1944, A graphic procedure in the geochemical interpretation of water analyses: American Geophysical Union Transactions, V. 25, pp. 914-923.

Sauer, V.B., 1974, Flood characteristics of Oklahoma streams: U.S. Geological Survey Water Resources Investigations 52-73, $301 \mathrm{p}$.

Shingleton, L.C., 1971, Soil survey of Pittsburg County, Oklahoma: U.S: Department of Agriculture, Soil Conservation Service, 60 p., 109 aerial-photo maps.

Thomas, W.O., Jr., and Corley, R.K., 1977a, Techniques for estimating flood depths for Oklahoma streams: U.S. Geological Survey Water Resources Investigation 2-76, $38 \mathrm{p}$.

Thomas, W.O., Jr., and Corley, R.K., 1977b, Techniques for estimating flood discharges for Oklahoma streams: U.S. Geological Survey Water Resources Investigation 77-54, $170 \mathrm{p}$.

U.S. Environmental Protection Agency, 1976, National interim primary drinking water regulations: U.S. Environmental Protection Agency EPA-580/9-76-003, $159 \mathrm{p}$. 